\title{
HEINONLINE
}

Citation: 62 Duke L.J. 975 2012-2013

Content downloaded/printed from

HeinOnline (http://heinonline.org)

Wed Sep 18 13:42:01 2013

-- Your use of this HeinOnline PDF indicates your acceptance of HeinOnline's Terms and Conditions of the license agreement available at http://heinonline.org/HOL/License

-- The search text of this PDF is generated from uncorrected OCR text.

-- To obtain permission to use this article beyond the scope of your HeinOnline license, please use:

https://www.copyright.com/ccc/basicSearch.do?

\&operation $=$ go\&search Type $=0$

\&lastSearch $=$ simple\&all=on\&titleOrStdNo $=0012-7086$

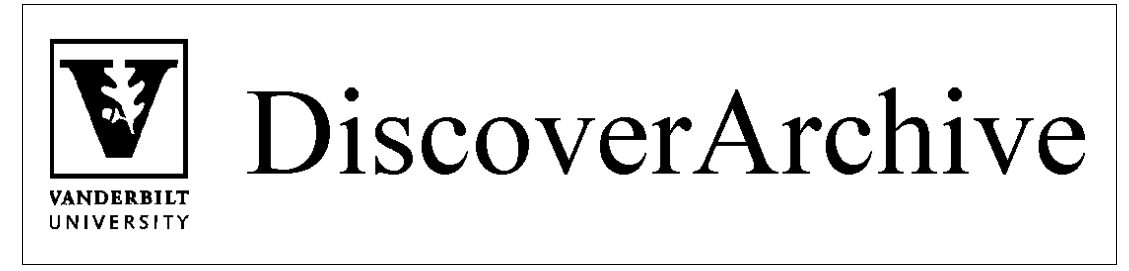

Retrieved from DiscoverArchive,

Vanderbilt University's Institutional Repository

This work was originally published as J.B. Ruhl \& James Salzman, Climate Change Meets the Law of the Horse in 62 Duke L.J. 975

2012-2013. 


\title{
Duke Law Journal
}

\begin{tabular}{lll}
\hline VOLUME 62 & FEBRUARY 2013 & NUMBER 5 \\
\hline
\end{tabular}

\section{CLIMATE CHANGE MEETS THE LAW OF THE HORSE}

\author{
J.B. RUHL $\dagger \&$ JAMES SALZMAN $\dagger \dagger$
}

\begin{abstract}
The climate-policy debate has only recently turned its full attention to adaptation-how to address the impacts of the climate change that we have already begun to experience and that will likely increase over time. Legal scholars have in turn begun to explore how the many different fields of law will and should respond. During this nascent period, one overarching question has gone unexamined: How will the legal system as a whole organize around climate change adaptation? Will a new, distinct field of climate adaptation law and policy emerge, or will legal institutions simply work away at the problem through unrelated, self-contained fields, as in the famous Law of the Horse? This Article is the first to examine that question comprehensively, to move beyond thinking about the law and climate change adaptation to consider the law of climate change adaptation.
\end{abstract}

Part I of the Article lays out our methodological premises and approach. Using a model we call Stationarity Assessment, Part I explores how legal fields are structured and sustained based on assumptions about the variability of natural, social, and economic conditions, and how disruptions to that regime of variability can lead to the emergence of new fields of law and policy. Case studies of

Copyright $\odot 2013$ by J.B. Ruhl and James Salzman.

$\dagger$ David Daniels Allen Distinguished Chair in Law, Vanderbilt University Law School.

†† Samuel F. Mordecai Professor of Law and Nicholas Institute Professor of Environmental Policy, Duke University. We are grateful for comments from Ann Carlson, Robin Craig, Steve McKinney, Alice Kaswan, and Kevin Stack, Rob Verchick and from workshop participants at the University of Colorado, UCLA, Pace, and Duke law schools and at the Association of American Law Schools mid-year meeting. Please contact us at jb.ruhl@vanderbilt.edu and salzman@law.duke.edu. 
environmental law and environmental justice demonstrate the model's predictive power for the formation of new, distinct legal regimes.

Part II applies the Stationarity Assessment model to the topic of climate change adaptation, using a case study of a hypothetical coastal region to demonstrate the potential for climate change impacts to disrupt relevant legal doctrines and institutions. We find that most fields of law appear to be capable of adapting effectively to climate change. In other words, without some active intervention, we expect the law and policy of climate change adaptation to follow the path of the Law of the Horse-a collection of fields independently adapting to climate change-rather than organically coalescing into a new and distinct field.

Part III explores why, notwithstanding this conclusion, it may still be desirable to seek a different trajectory. Focusing on the likelihood of systemic adaptation decisions with perverse and harmful results, we identify the potential benefits offered by intervening to shape a new and distinct field of climate adaptation law and policy. Part $I V$ then identifies the contours of such a field, exploring the distinct purposes of reducing vulnerability, ensuring resiliency, and safeguarding equity. These features provide the normative policy components for a law of climate change adaptation that would be more than just a Law of the Horse. This new field would not replace or supplant any existing field, however, as environmental law did with regard to nuisance law, and it would not be dominated by substantive doctrine. Rather, like the field of environmental justice, this new legal regime would serve as a holistic overlay across other fields to ensure more efficient, effective, and just climate adaptation solutions.

\section{TABLE OF CONTENTS}

Introduction .977

I. Anticipating New Legal Fields .985

A. On the Law of the Horse and Why It Matters....................985

B. Stationarity-Based Design in Law and Policy.....................990

1. Stationarity in Natural Systems

2. The Stationarity Assessment Model for Legal Fields .....993

3. Testing the Model for Environmental Law and Environmental Justice

II. Stationarity Assessment of Climate Change and Law

A. Stationarity Assessment Case Study 1002

B. Assessment of Legal Fields .1003

C. Calling a Horse a Horse 
III. Justifying an Intervention .............................................................1014

A. Changing the Scale of Stationarity Assessment................1014

B. Adaptation as Process, Not Substance ..............................1017

IV. Designing a Field of Climate Change Adaptation.......................1019

A. Policy Goals .......................................................................1020

B. Procedural Overlay Implementation Mechanisms...........1023

Conclusion........................................................................................1026

A few years ago, at a conference on the "Law of Cyberspace" held at the University of Chicago, Judge Frank Easterbrook told the assembled listeners ... that there was no more a "law of cyberspace" than there was a "Law of the Horse"; that the effort to speak as if there were such a law would just muddle rather than clarify; and that legal academics ("dilettantes") should just stand aside as judges and lawyers and technologists worked through the quotidian problems that this souped-up telephone would present. "Go home," in effect, was Judge Easterbrook's welcome.

\section{INTRODUCTION}

Climate change is here. Its impacts are present in the current landscape, and, barring miraculous developments in politics and technology, it will be a part of the future for our generation and for

1. Lawrence Lessig, The Law of the Horse: What Cyberlaw Might Teach, 113 HARV. L. REv. 501, 501 (1999) (footnote omitted); see also Frank H. Easterbrook, Cyberspace and the Law of the Horse, 1996 U. CHI. LEGAL F. 207, 207-16 (presenting a written version of the speech quoted in the text). The "Law of the Horse" is an old catch phrase used to refer to an unnecessary effort to bring together unrelated and duly self-contained bodies of law. See id. at 207 ("Lots of cases deal with sales of horses; others deal with people kicked by horses; still more deal with the licensing and racing of horses, or with the care veterinarians give to horses, or with prizes at horse shows. Any effort to collect these strands into a course on 'The Law of the Horse' is doomed to be shallow and to miss unifying principles."). Judge Easterbrook credits the phrase to Karl Llewellyn. Id. at 214 (citing Karl N. Llewellyn, Across Sales on Horseback, 52 HARV. L. REV. 725, 735, 737 (1939); and Karl N. Llewellyn, The First Struggle To Unhorse Sales, 52 HARV. L. REV. 873 (1939)).

2. See Intergovernmental Panel on Climate Change, Climate Change 2007: SYNTHESIS REPORT 72 (2007), available at http://www.ipcc.ch/publications_and_data/publications_ipcc_fourth_assessment_report_synthesis_report.htm ("Many natural systems, on all continents and in some oceans, are being affected by regional climate changes. Observed changes in many physical and biological systems are consistent with warming."); U.S. GLOBAL Change Research Program, Global Climate Change IMPaCtS IN THE UNITEd STATES 9 (2009), available at http://downloads.globalchange.gov/usimpacts/pdfs/climate-impactsreport.pdf ("Observations show that warming of the climate is unequivocal. The global warming observed over the past 50 years is due primarily to human-induced emissions of heat-trapping gases."). 
many to follow. ${ }^{3}$ By our very nature, humans are adaptable creatures, but those skills will surely be put to the test in the face of changes in sea level, surface temperature, rainfall, snowmelt, ecosystems, and a myriad of other shifting conditions, some gradual and some abrupt. ${ }^{4}$ For some people, in some places, changes will be for the betterthink agriculture in Siberia - while for other people in other places the prospect is dire-consider the low-lying Solomon Islands. ${ }^{5}$ The challenge is clear, the question obvious: What should law and policy do about the impacts of climate change?

3. See Intergovernmental Panel on Climate Change, supra note 2 , at 72 ("Anthropogenic warming and sea level rise would continue for centuries even if [greenhousegas] emissions were to be reduced sufficiently for [greenhouse-gas] concentrations to stabilise, due to the time scales associated with climate processes and feedbacks."); V. Ramanathan \& Y. Feng, On Avoiding Dangerous Anthropogenic Interference with the Climate System: Formidable Challenges Ahead, 105 PROC. NAT'L ACAD. SCI. 14,245, 14,245 (2008) (estimating a committed warming of $2.4^{\circ} \mathrm{C}$ even if greenhouse-gas concentrations are held to 2005 levels); Susan Solomon, Gian-Kasper Plattner, Reto Knutti \& Pierre Friedlingstein, Irreversible Climate Change Due to Carbon Dioxide Emissions, 106 PROC. NAT'L ACAD. SCI. 1704, 1704 (2009) (estimating a one-thousand-year committed warming effect).

4. For overviews of the likely global and domestic impacts, see generally INTERgovernmental PaNel on Climate Change, supra note 2; and U.S. Global CHANGE RESEARCH PROGRAM, supra note 2.

5. Climate change is not all about harms-there will be benefits in many forms for many regions of human populations and for many species. Agriculture in the United States, for example, may find benefits from warming temperatures, increased precipitation, and higher carbon-dioxide levels. See Olivier Deschênes \& Michael Greenstone, The Economic Impacts of Climate Change: Evidence from Agricultural Output and Random Fluctuations in Weather, 97 AM. ECON. REV. 354, 355 (2007) ("If anything, climate change appears to be slightly beneficial for profits and yields."). In particular, and of relief to many, "the production of high-quality wine grapes is expected to benefit from a warmer climate because of a longer growing season and more favorable growing conditions in the short-term." CAL. NATURAL RES. AGENCY, 2009 CAlifornia Climate AdAPTATION STRATEGy 94 (2009), available at http://resources.ca.gov/ climate_adaptation/docs/Statewide_Adaptation_Strategy.pdf. Most of the national-scale economic-impact studies show Russia and Eastern Europe as best off under a range of climate change scenarios, with small to substantial increases in GDP, and Africa, parts of Asia, and small island states as worst off. See RICHARD S.J. TOL, AN ANALYSIS OF Mitigation as A RESPONSE TO CLIMATE CHANGE 6 tbl.1 (2009), available at http:/fixtheclimate.com/ uploads/tx_templavoila/AP_Mitigation_Tol_v_3.0.pdf (presenting a chart based on synthesis of over a dozen economic studies). For an examination of the impact of climate change on small islands, see infra note 134.

6. For summaries of the legal and policy issues likely to come with climate change, including reviews and syntheses of scientific and legal literature on the topic, see generally Alejandro E. Camacho, Adapting Governance to Climate Change: Managing Uncertainty Through a Learning Infrastructure, 59 EMORY L.J. 1 (2009); Robin Kundis Craig, "Stationarity Is Dead"-Long Live Transformation: Five Principles for Climate Change Adaptation Law, 34 Harv. EnvTl. L. Rev. 9 (2010); Holly Doremus, Adapting to Climate Change with Law That Bends Without Breaking, 2 SAN DIEGO J. ClimATE \& ENERGY L. 45 (2010); Robert L. Glicksman, Ecosystem Resilience to Disruptions Linked to Global Climate Change: An Adaptive 
The answer is equally clear: climate change adaptation. ${ }^{7}$ We must adapt to our new circumstances in their many specific settings as best we can. On that much we can all agree. Alas, what this adaptation entails is far less clear. Like the early explorers' maps that filled in distant seas and lands with the hopeful, enigmatic phrase, terra incognita, there is no analog from humanity's climate past on which to chart humanity's climate future. ${ }^{8}$

Given the daunting challenges of this uncertain future, decisionmakers are increasingly concerned about the "adaptation deficit" in climate change law and policy that has amassed over time." Until very recently, the focus on climate change mitigation, particularly reducing greenhouse-gas emissions, has held center stage. ${ }^{10}$ Debates over mitigation-how much and how fast to reduce causes of climate change-largely crowded out considerations of

Approach to Federal Land Management, 87 NEB. L. REv. 833 (2009); and J.B. Ruhl, Climate Change Adaptation and the Structural Transformation of Environmental Law, 40 ENVTL. L. 363, 365-71 (2010).

7. Climate change "adaptation" refers to "measures to improve our ability to cope with or avoid harmful impacts and take advantage of beneficial ones, now and in the future." U.S. GLOBAL ChANGE RESEARCH PROGRAM, supra note 2, at 8.

8. Ecologists now warn of the no-analog future-ecological variability unprecedented in the history of ecology, riddled with nonlinear feedback and feed-forward loops, previously unknown emergent properties, and new thresholds of irreversible change. See, e.g., Matthew C. Fitzpatrick \& William W. Hargrove, The Projection of Species Distribution Models and the Problem of Non-Analog Climate, 18 BIODIVERSITY \& CONSERVATION 2255, 2255 (2009) ("By 2100 , a quarter or more of the Earth's land surface may experience climatic conditions that have no modern analog .... [L]ittle information exists to predict how species may respond under [these] novel environments."); Douglas Fox, Back to the No-Analog Future?, 316 SCIENCE 823, 823 (2007) (" $[\mathrm{I}] \mathrm{f}$ the climate changes over the next 100 years as current models predict, surviving species throughout much of Earth's land area will not simply migrate north and south en masse as unchanging communities, as Charles Darwin once believed. Instead, they are likely to be reshuffled into novel ecosystems unknown today."); Douglas Fox, When Worlds Collide, CONSERVATION, Jan.-Mar. 2007, at 28, 31 (arguing that it is likely that the world will enter into a no-analog future within one hundred to two hundred years).

9. See Ian Burton, Climate Change and the Adaptation Deficit, in THE EARTHSCAN Reader on Adaptation to Climate Change 89, 90-92 (E. Lisa F. Schipper \& Ian Burton eds., 2009) (describing economic losses that have resulted from unpreparedness for weather catastrophes related to climate change, and noting the "demand for attention to adaptation" at meetings of the United Nations Framework Convention on Climate Change).

10. See Ruhl, supra note 6, at 365-66 ("[T]he policy world's fixation on achieving, or blocking, federal greenhouse gas emission legislation as part of our national strategy for climate change mitigation has contributed to our neglect of national policy for climate change adaptation." (footnote omitted)). Climate change "mitigation" refers to "measures to reduce climate change by, for example, reducing emissions of heat-trapping gases and particles, or increasing removal of heat-trapping gases from the atmosphere." U.S. GLOBAL CHANGE RESEARCH PROGRAM, supra note 2, at 11. 
adaptation-how best to manage the impacts of climate change. ${ }^{11}$ Only now, facing the stark realities of the United Nations climate negotiations ${ }^{12}$ and the failure to pass climate legislation in Congress, ${ }^{13}$ has climate-policy dialogue in the United States started to shift ground to incorporate adaptation as a significant policy component. ${ }^{14}$

It stands to reason that the demands of climate change adaptation will present new kinds of challenges and conflicts for public and private legal institutions. It is no surprise, therefore, that a flood of recent scholarship has focused on the implications of climate change adaptation for the law-exploring how law will adapt in fields as varied as insurance, environmental, immigration, water supply, torts, energy, and property, to name just a few-while crosscutting issues such as federalism and human rights are also receiving careful attention. ${ }^{15}$

Some scholars, however, have gone beyond examining discrete fields of law, predicting that climate change adaptation could become a broadly transformative agent of legal change. For example, Professor Robin Craig argues that climate change adaptation will demand both "new ways of thinking about law" and "a new legal framework," $" 16$ and offers ideas about some core principles of this

11. See Ruhl, supra note 6 , at $365-70$ (recounting the history of policy attention to mitigation at the expense of attention to adaptation).

12. With the collapse of negotiations at Copenhagen, the prospect of global caps on greenhouse-gas emissions has become remote. See, e.g., Elisabeth Rosenthal, Where Did Global Warming Go?, N.Y. TiMEs, Oct. 15, 2011, at A1.

13. Although the House of Representatives passed the American Clean Energy and Security Act of 2009 (Waxman-Markey Bill), H.R. 2454, 111th Cong. (2009), climate legislation died in the Senate, and there has been no attempt to reintroduce legislation. During the 2012 presidential campaign, none of the presidential candidates pushed the prospect of new legislation. See, e.g., GOP Presidential Hopefuls Shift on Global Warming, USA TODAY (May 27, 2011), http://usatoday30.usatoday.com/news/politics/2011-05-27-presidential-hopefuls-globalwarming_n.htm. In President Obama's first press conference following his reelection, he signaled that climate change legislation would not be a top priority in his second term. Andrew Restuccia, President Obama Says Climate Change To Take Backseat to Economy, POLITICO (Nov. 14, 2012, 4:19 PM EST), http://www.politico.com/news/stories/1112/83865.html.

14. See Ruhl, supra note 6, at 370-75 (discussing this shift in focus). The consensus now is that "mitigation and adaptation are both essential parts of a comprehensive climate change response strategy," though much remains to be worked out. U.S. GLOBAL CHANGE RESEARCH PROGRAM, supra note 2, at 11.

15. For a broad survey of the legal literature on climate change adaptation, see Ruhl, supra note 6, at 391-432. For a reference book with chapters on agriculture, energy systems, insurance, financing, and more, see generally THE LAW OF ADAPTATION TO CLIMATE CHANGE: U.S. AND INTERNATIONAL ASPECTS (Michael Gerrard \& Katrina Fischer Kuh eds., 2012).

16. Craig, supra note 6 , at 17. 
"new climate change adaptation law." ${ }^{17}$ Nor is she alone. A growing number of commentators believe that climate change will impose radical changes on society and that the law will, perforce, need to adapt in similarly radical ways. ${ }^{18}$

These are bold claims with significant implications for the evolution of legal doctrine and institutions. But will the profound need for social and economic adaptations to climate change create an equally profound need for legal adaptations? If so, are those adaptations likely to evolve through incremental changes across numerous existing fields of law, or will they demand the formation of a new, distinct field of climate adaptation law? To paraphrase Judge Easterbrook's quote at the head of this Article, ${ }^{19}$ it remains to be seen whether law and policy for climate change adaptation will evolve as a disconnected Law of the Horse or coalesce into a coherent fieldwhether it becomes a law and climate change adaptation or a law of climate change adaptation.

Nor is the and/of distinction merely a semantic quibble. As law school course offerings seem designed to prove, there can be a law and anything. Law of implies something more, that there is a need for the legal system to respond to change from outside by changing inside at a more fundamental level. This Article is therefore intended to initiate a debate over the potential trajectories of climate adaptation law, examining not only whether a new, distinct field is likely to coalesce around the policies implicated by climate change adaptation

17. See id. at $17,40-69$ (suggesting and elaborating upon five broad principles that, implemented over time, can effectively guide the law's response to climate change).

18. See, e.g., Carl Bruch, The End of Equilibrium, ENVTL. F., Sept.-Oct. 2008, at 30, 35 (outlining the need for "adaptation law"); John C. Dernbach \& Seema Kakade, Climate Change Law: An Introduction, 29 ENERGY L.J. 1, 2 (2008) (describing the emergence of "climate change law" at "the intersection of several areas of law, including environmental law, energy law, business law, and international law"); Jan McDonald, The Role of Law in Adapting to Climate Change, 2 CLIMATE CHANGE 283, 284 (2011) (proposing "design requirements of a legal framework for addressing the peculiar challenges posed by climate change risks"); Jacqueline Peel, Climate Change Law: The Emergence of a New Legal Discipline, 32 MELB. U. L. REV. 922, 924 (2008) ("[D]evising legal solutions to climate change is likely to involve profound changes to existing governance and regulatory frameworks, with reverberations felt in many other areas of law such as constitutional law, administrative law and property law."); Richard J. Pierce, Jr., Legal Disputes Related to Climate Change Will Continue for a Century, 42 Envtl. L. 1257, 1273 (2012) (arguing that the "steps we must take to adapt to climate change...will involve major changes in the legal environment"); Matthew D. Zinn, Adapting to Climate Change: Environmental Law in a Warmer World, 34 ECOLOGY L.Q. 61, 82 (2007) ("Environmental law, as it stands or as it might be foreseeably reconfigured, may lack the capacity to respond to the threats posed by adaptation to climate change.").

19. See supra note 1 and accompanying text. 
but, more to the point, whether one should. We take a close look at whether and how lawyers could purposively take part in that creation moment-to choose whether to let the Law of the Horse run its course or to pursue a law of climate change adaptation.

Precisely because the future trajectory remains uncertain, the time to engage in this analysis is now. Decisions made today about climate change adaptation-whether shaping the course of evolution or sitting back and watching the drama unfold-may become "sticky," leading to path dependence and making it increasingly difficult to change course if the need becomes apparent. ${ }^{20}$ If the stakes are high, as they are likely to be with climate change, it is worth thinking now about how to avoid going down the wrong path.

To make this discussion more concrete, consider the case of environmental law, regarded as one of the most complex and specialized fields of practice, with many of its own distinct problems, doctrines, tools, institutions, and methods. ${ }^{21}$ The need for a law of the environment may seem self-evident today, but its emergence as a distinct field is relatively recent. The very term "environmental law" did not even exist before $1969 .^{22}$ In the 1970 s, policymakers, lawyers, activists, and legal scholars explicitly conceived of the law of the environment as something more than just a bunch of unrelated legal challenges that happened to intersect at the common factual ground of the human impact on nature..$^{23} \mathrm{~A}$ similar story could be told about the field of environmental justice and its genesis in the late 1980s to manage the distributional effects of environmental, land use, and other policy realms. ${ }^{24}$ Recognized today as significant and separate

20. See Oona A. Hathaway, Path Dependence in the Law: The Course and Pattern of Legal Change in a Common Law System, 86 IOWA L. REV. 601, 631, 641 n.161 (2001) ("[C]haracteristics of the common law process lead a particular resolution of a legal issue to become locked in; courts find it increasingly difficult to depart from the path once the first few steps are taken.").

21. See Todd S. Aagaard, Environmental Law as a Legal Field: An Inquiry in Legal Taxonomy, 95 CORNELL L. REV. 221, 251-82 (2010) (arguing that, despite doctrinal variation and even incoherence, identifiable core patterns frame environmental law as a discrete legal field).

22. RICHARD J. LAZARUS, THE MAKING OF ENVIRONMENTAL LAW 47 (2004) (describing key players behind the formation of environmental law).

23. See id. at 79-84 (describing the 1970 s as a "new era" during which stringent Congressional oversight of agencies, citizen suits initiated pursuant to new statutes, and an enthusiastic, exacting judiciary all combined to "serve[] an essential supporting role in maintaining environmental law").

24. The field of environmental justice law exploded in dimensions during the $1990 \mathrm{~s}$. See generally, e.g., CHRISTOPHER H. Foreman, JR., THE PrOMISE AND PERIL OF 
areas of theory and practice, the origins of environmental law and environmental justice as distinct legal fields were intentional.

Ocean-management policy provides a clear contrast. For decades, laws relating to the oceans took a passive Law-of-the-Horse approach that virtually all policymakers and scholars now consider to have produced a dysfunctional and ineffective legal regime. ${ }^{25}$ Accreting over time, today the "Law of the Oceans" comprises a crazy quilt of twenty federal agencies overseeing 140 statutes ${ }^{26}$ Long entrenched in this Law-of-the-Horse approach, recent and repeated calls to overhaul this patchwork into a consolidated, coherent field of law centered around oceans management have gained little traction. ${ }^{27}$ Despite best efforts, it remains a Law of the Horse.

Part I thus opens the inquiry by examining what it means to refer to a new and distinct field of law and why it is important to anticipate when one may be needed for effective implementation of emerging policy goals. To probe when new fields are likely to form, we develop an analytical framework known as a Stationarity Assessment. Extending the recent work of water-resource managers, ${ }^{28}$ a Stationarity Assessment assesses why and when distinct fields evolve

ENVironmental Justice (1998); KenNeth A. Manaster, ENVIRonmental Protection AND JUSTICE: READINGS AND COMMENTARY ON ENVIRONMENTAL LAW AND PRACTICE (1st ed. 1995); DAVID E. NeWTON, ENVIRONMENTAL JUSTICE: A REFERENCE HANDBOOK (1st ed. 1996); Symposium, Environmental Burdens and Democratic Justice, 21 FORDHAM URB. L.J. 425 (1994); Symposium, Race, Class, and Environmental Regulation, 63 U. COLO. L. REV. 839 (1992). For thorough bibliographies of the deep and broad environmental justice literature that had developed even by the mid-1990s, see generally Adam D. Schwartz, The Law of Environmental Justice: A Research Pathfinder, 25 ENVTL. L. REP. 10,543 (1995); and Carita Shanklin, Pathfinder: Environmental Justice, 24 ECOLOGY L.Q. 333 (1997).

25. See, e.g., L.B. Crowder et al., Resolving Mismatches in U.S. Ocean Governance, 313 SCIENCE 617, 617 (2006) ("Historically, ocean management has focused on individual sectors.... Separate regimes for fisheries, aquaculture, marine mammal conservation, shipping, oil and gas, and mining are designed to resolve conflicts within sectors, but not across sectors."); Christopher Shane Studley, Ocean Policy and Change: Is There Hope for Ocean Reform?, 18 SOUTHEASTERN ENVTL. L.J. 105, 105-11 (2009) (tracing the development of the United States's "fractured and dysfunctional national policy for ocean management").

26. Crowder et al., supra note 25 , at 617.

27. Professor Larry Crowder and his coauthors argue that because the declining ocean conditions "are largely due to failures of governance, reversing them will require new, more effective governance systems," yet they recognize that "these governance problems are difficult to alleviate even after they become well understood." Id. at 617-18; see also Studley, supra note 25 , at 111-31 (providing an overview of proposed reforms but concluding that "[ $\mathrm{t}]$ here are many obstacles to overcome before ocean policy reform occurs").

28. See P.C.D. Milly, Julio Betancourt, Malin Falkenmark, Robert M. Hirsch, Zbigniew W. Kundzewicz, Dennis P. Lettenmaier \& Ronald J. Stouffer, Stationarity Is Dead: Whither Water Management?, 319 SCIENCE 573 (2008). 
in response to disruptions to those fields' underlying natural, social, and economic foundations. Part I explains the details of the Stationarity Assessment model and applies it to the histories of environmental law and environmental justice to demonstrate its explanatory power.

Part II applies the Stationarity Assessment model to a case study of climate change adaptation in a diverse coastal region feeling the environmental, social, and economic effects of climate change. Rising mean surface temperatures, sea-level rise, changes in precipitation, and other changes are likely to present pressing and in some cases novel kinds of legal issues, but we find that for most purposes a Lawof-the-Horse approach will be adequate-existing doctrines and institutions in the relevant fields of law can effectively adapt to the changed conditions. In a small number of fields, however, notably those with foundations that rest heavily on stationarity assumptions of biophysical conditions, the law will be put under such intense pressure that current doctrines and institutions will need to respond with more deliberate and potentially substantial adaptation. Nevertheless, we conclude that there is little reason to believe that even these fields will radically transform when faced with the challenges of climate change adaptation. In short, it is difficult to envision how climate change adaptation will necessitate dramatic transformations of the doctrinal foundations and institutional architecture of any particular field of law, much less lead to the organic evolution of a new field of climate adaptation law.

Part III explores why, notwithstanding this conclusion, it may still be desirable to seek a different trajectory, to intervene intentionally and create a new and distinct field of climate adaptation law and policy. Adapting to the impacts of climate change will vary depending on each location's geography and vulnerabilities. As a result, any need for new substantive law and policy will likely be place- and topic-specific. At the systemic level, however, adaptation decisions will implicate multiple actors and concerns across different landscapes, sectors, and communities. It is at this systemic scale that a new field focused on procedure rather than substance would be most useful to guard against and manage unintended, perverse responses to climate change impacts.

This conclusion has major implications for how lawyers and legal institutions approach climate change adaptation. Part IV thus identifies the contours of such a nascent field, exploring adaptation's distinct goals of reducing vulnerability, ensuring resiliency, and 
safeguarding equity. These features provide the normative components for a law of climate change adaptation that would make it more than just a Law of the Horse. The climate adaptation field we envision, however, would not replace or supplant any existing field, as environmental law did with regard to nuisance law, ${ }^{29}$ and it would not be dominated by substantive doctrine, as is largely the case under environmental law. Rather, as environmental justice has done for environmental, land use, and public-infrastructure-and-services law, ${ }^{30}$ this new field would function as a procedural overlay to ensure more efficient, effective, and just climate adaptation solutions across the spectrum of other legal fields.

\section{ANTICIPATING NEW LEGAL FiELDS}

Legal scholars since the heyday of the legal realism movement have considered what makes fields of law distinct, why lawyers refer to this field of law and that field of law, but not others, and whether fields should be defined by their structure or focus of study. ${ }^{31}$ Notwithstanding this rich scholarly history, "no ultimate authority exists for defining a field of law." be defined by its own practitioners for their purposes or tastes. The test of its validity lies in whether others accept it." ${ }^{, 33}$ Whether others should accept the pronouncement of new fields lay at the heart of the cyberspace law debate captured by Judge Easterbrook's comments. This Part draws on the tensions of that debate and considers what it means generally to describe a collection of laws and policies as a field and why new fields of law emerge.

\section{A. On the Law of the Horse and Why It Matters}

There is no better starting point for considering what makes a field of law distinct and useful than the classic nonfield of law-the fabled "Law of the Horse." There is, of course, no coherent Law of the Horse, which was the point of Judge Easterbrook's derisive comments. Legal issues concerning horses arise across a range of

\footnotetext{
29. See infra Part I.B.3.

30. See infra Part I.B.3.

31. See Wendy K. Mariner, Toward an Architecture of Health Law, 35 AM. J.L. \& MED. 67, 79-82 (2009) (describing the process by which various legal fields have arisen, with attention to the different approaches that have been employed to define these discrete fields).

32. Id. at 82 .

33. Id.
} 
practice fields-veterinary law, racing law, agricultural law, consumer law, and so on. ${ }^{34}$ This is not merely an equine observation. Take rain, for example. It falls on many aspects of our lives, but it would be nonsensical to think of "rain law" as a distinct field. Rather, questions as varied as who has rights to rain once it falls, whether someone can treat clouds to induce or prevent rain, how event planners can insure against unwanted rain, liability for damages from rain, and how to respond to flooding from too much rain are divvied out to a broad variety of public- and private-law fields. ${ }^{3.5}$ To describe someone as a "horse lawyer" or a "rain lawyer," in other words, is meaningless.

Hence Judge Easterbrook's challenge to self-proclaimed cyberspace lawyers a decade ago. Although everyone acknowledged that the Internet and its allied technologies had ushered in remarkable changes, it was less clear that this compelled the development of a correspondingly distinct "Law of Cyberspace." Easterbrook argued that there was no need for anything of the sort, that the Law of Cyberspace was a meaningless fiction no more useful than a Law of the Horse. ${ }^{36}$ There might be plenty of new legal issues associated with the emergence and growth of cyberspace, but judges and lawyers could effectively adapt existing doctrines, tools, and methods of law across a multitude of fields to work through them, albeit sometimes in novel and different combinations and applications. $^{37}$

Similarly, climate change will put pressure on law to adapt, of that there is no doubt. But is the idea of a "Law of Climate Change Adaptation," like the "Law of Cyberspace," no more than a fatuous

34. See supra note 1. To be fair, though, some do speak of horse law. The law firm of Foster Swift, for example, maintains the Equine Law Blog. EQUINE LAW BLOG, FOSTER SWIFT COLLINS \& SMITH P.C., http://www.equinelawblog.com.

35. As some simple searches in Westlaw and Lexis databases demonstrated to us, law and commentary on all of these issues are easy to locate through traditional legal research, whereas after similar efforts to find law and commentary on a distinct "law of rain" or "rain law" field of theory or practice, we can confirm that it does not exist.

36. See Easterbrook, supra note 1, at 207 ("When asked to talk about 'Property in Cyberspace,' my immediate reaction was, 'Isn't this just the law of the horse?'").

37. As Judge Easterbrook explained:

Error in legislation is common, and never more so than when the technology is galloping forward. Let us not struggle to match an imperfect legal system to an evolving world that we understand poorly. Let us instead do what is essential to permit the participants in this evolving world to make their own decisions. That means three things: make rules clear; create property rights where now there are none; and facilitate the formation of bargaining institutions. Then let the world of cyberspace evolve as it will, and enjoy the benefits.

Id. at 215-16. 
Law of the Horse? How would we know-how do we tell the Law of the Horse from the law of anything else?

Some insight on this can be drawn from the debate that surrounded cyberspace law. Judge Easterbrook did not have the last word, as lawyers continued to hash out why cyberspace does or does not warrant the distinction of a legal field. On the side of describing cyberlaw as a distinct field, scholars focused on its "usefulness of joint treatment of similar problems. ${ }^{" 38}$ This useful role for a distinct field, they argued, derives from the uniqueness of the underlying structure of the cyberspace subject matter, the new infrastructure that the Internet provides for information markets and other social practices, and novel questions of cyberspace governance. ${ }^{39}$ To generalize their argument, new fields of law are likely to emerge when some external force-in that case technology-presents profoundly novel subject matter, socioeconomic conditions, and governance challenges for law.

On the other side of the debate came arguments that the technological novelty of the Internet served as no more reason to craft a new field of law than was, say, the automobile. As one skeptic argued, "[v]ery few bodies of law are defined by their characteristic technologies. Tort law is not 'the law of the automobile,' even though the auto accident is the paradigmatic tort case." ${ }^{, 40}$ The newness of the Internet, they concluded, thus served as no basis for a distinct field of law even if it did lead to novel social practices, as "even new social practices are often well served by traditional legal devices." ${ }^{41}$ Reinforcing Judge Easterbrook's assessment, one scholar summed up that

most legal doctrines are flexible and likely to accommodate new social practices in their interstices. Filling interstices may be a form of novelty, but can be no more than an interstitial one. Therefore, most novel law resembles an extension or amalgamation of familiar

38. Viktor Mayer-Schönberger, The Shape of Governance: Analyzing the World of Internet Regulation, 43 VA. J. INT'L L. 605, 608 (2003). Writing about environmental law, Professor Todd Aagaard similarly observed that

[a] field of law must exhibit some degree of commonality, a characteristic or set of characteristics shared in common by the situations that arise within the area of law that the field encompasses. Commonalities establish patterns that cohere the field. ... Only when the common characteristics are legally relevant do the materials they encompass appear as an identifiable corpus.

Aagaard, supra note 21, at 242.

39. Mayer-Schönberger, supra note 38, at 608-10.

40. Joseph H. Sommer, Against Cyberlaw, 15 BERKELEY TECH. L.J. 1145, 1147 (2000).

41. Id. at 1148 . 
legal categories. ... Of course, legal doctrines will change; they always do. The new information technologies will trigger some of these changes. But with a few exceptions, these changes will exist only in the details. ${ }^{42}$

Even the most ardent critics of cyberspace law as a field conceded, however, that "substantial changes to the legal landscape sometimes occur." ${ }^{43}$ Sometimes, in other words, the interstices of existing fields are simply not of sufficient volume to hold all of the novelty that some new agent of change is throwing at the legal system-a new field is needed.

But why try to create a field? The distinction between the Law of the Horse and a coherent field of law is more than semantic. Credible, legitimate fields of law serve at least three important purposes. First, they can provide a forceful political statement. It is no coincidence that broad and deeply rooted social movements, such as environmentalism in the 1970 s and sexual orientation in the 1980s, eventually also became associated with distinct fields of law and policy. Early advocates in these fields wrote textbooks. ${ }^{44}$ These not only made the case that particular issues, laws, and policies should be conceived as discrete fields but paved the way for law school courses in these fields, training the next generation of lawyers to think of these as credible, legitimate areas of practice. ${ }^{45}$ Interestingly, advocates of Disaster Law are attempting precisely the same thing right now. Concerned over inadequate responses to Hurricane Katrina and social-justice issues, Professors Dan Farber, Rob

42. Id. As Professor Aagaard similarly has observed,

[a]n area of law unified only by factual commonality-that is, a common factual characteristic or characteristics that make no difference to the application of the law-is, like the Law of the Horse, a joke rather than a legitimate field of legal study because the various laws that govern activities related to horses have nothing legally important in common.

Aagaard, supra note 21, at 242 (citation omitted).

43. Sommer, supra note 40 , at 1148 .

44. For an early textbook on environmental law, see, for example, FRANK P. GRAD, ENVIRONMENTAL LAW: SOURCES AND PROBLEMS (1st ed. 1971). For an early textbook on sexual-orientation law, see, for example, LESBIANS, GAY MEN, AND THE LAW (William B. Rubenstein ed., 1993).

45. Professors Dan Mandelker and Dan Tarlock played this role in environmental law, with their pathbreaking casebooks. See EVA H. HANKS, A. DAN TARLOCK \& JOHN L. HANKS, CASES AND MATERIals ON ENVIRONMENTAL LAW AND PoliCY (1974); Daniel Mandelker, Managing OUR Urban Environment: Cases, TeXt \& Problems (2d ed. 1971). Professor Bill Rubenstein played a similar role with the publication of his pathbreaking LESBIANS, GAY MEN, AND THE LAW, supra note 44, known in subsequent editions as CASES AND MATERIALS ON SEXUAL ORIENTATION AND THE LAW. 
Verchick, and other scholars have published a casebook and are encouraging the teaching of Disaster Law courses. ${ }^{46}$

Second, fields can increase efficiency. If highly technical or deep knowledge is not widely available to address important crosscutting issues, it may make sense to form a new field around that specialized knowledge rather than force an existing field to morph itself to absorb the topic whole. Hence the ascendance of food-and-drug law or telecommunications law. Similarly, because of rising public interest or commercial importance, it may be more efficient to think of different fields operating under the same umbrella-think of sports law and its selective drawing from contracts, torts, insurance, and other legal fields. ${ }^{47}$ Finally, the current legal pastiche may prove to be inadequate. The paradigm simply fails to get the job done. This was the case for reliance on nuisance doctrines for environmental protection and arguably is so for health law's inadequate reliance on tort and contracts. ${ }^{48}$

Depending on the circumstances, then, creation of a new field can serve political ends by legitimating a social movement, enhance efficiency by providing a focal area for technical expertise, ensure effectiveness by reorienting laws and policies in a more productive structure, or some combination of all three. The main point is that the developing a field of law both implies and signifies more than coming up with a faddish name.

46. DANiel A. FARber, Jim CHEN, Robert R.M. VERCHICK \& LiSA Grow SUN, DISASTER LAW AND POLICY (2d ed. 2010); see also Symposium, Disaster Law, 23 DUKE ENVTL. L. \& POL'Y F. 1 (2013). See generally Disaster Law, U.C. BERKELEY SCH. OF LAW, http://www.law.berkeley.edu/1374.htm (describing the Disaster Law course, blog, and resources at the University of California, Berkeley). So, too, have casebooks started appearing on climate change law. See generally, e.g., HARI OsOFSKY, WILliAM C.G. BURNS \& LESLEY K. MCAllister, Climate Change Law AND Policy (2012); Chris Wold, David Hunter \& Melissa Powers, Climate Change and the Law (2009).

47. See generally PAUL C. WEILER, GARY R. ROBERTS, ROGER I. ABRAMS \& STEPHEN F. ROSS, SPORTS AND THE LAW: TEXT, CASES AND PROBLEMS (4th ed. 2010) (describing the various fields of law implicated in sports-related issues).

48. The coherence of health law as a field nonetheless remains in question. See, e.g., Einer R. Elhauge, Can Health Law Become a Coherent Field of Law?, 41 WAKE FOREST L. REV. 365 (2006) (noting the disjointed state of the law governing health issues); Mark A. Hall, The History and Future of Health Care Law: An Essentialist View, 41 WAKE FOREST L. REV. 347, 354 (2006) (describing health law as a "hodgepodge" composed of four separate and distinct branches). 


\section{B. Stationarity-Based Design in Law and Policy}

One can imagine two distinct trajectories for climate adaptation law and policy.

- A New Field of Climate Change Adaptation. Discrete areas of law develop increasingly tight interconnections around climate change adaption policies that lead legal doctrines and institutions to coalesce into a distinct, coherent field with principles all its own.

- A Law of the Horse. Combinations of different existing fields occasionally intersect as needed to work on adaptation solutions, forming nothing more coherent than a Law of the Horse.

Neither course is self-evident circa the vantage of 2013. Just as early environmental lawyers did in the 1970 s, environmental justice advocates did in the 1980s, and cyberspace lawyers did in the 1990s, considering these issues for climate change adaptation now is important for the simple reason that how climate adaptation law and policy are thought of today will influence their design and implementation well into the future. In short, better to get it right for climate change adaptation at a nascent stage, or at least to think carefully about which is the better organizational approach, than to have the lawyers of the future look back and wish that a different path had been taken.

Our first step is to assess which path the law, in the face of climate change impacts, is likely to follow without intervention. To do so, in this Section we develop a general, predictive model for when new fields of law coalesce in response to episodes of social, economic, technological, or environmental change.

1. Stationarity" in Natural Systems. Since the dawn of cities, communities have needed to manage their water resources. Particularly in water-scarce areas, water engineers have faced decisions over when and where to build costly infrastructure. This need was as true for ancient Rome's aqueducts as it is for today's desalination plants. In all cases, managers must necessarily assume boundaries of natural system variability to make reliable and costeffective short-term and long-term decisions. An understanding of 
how much water supplies vary from year to year is critical to planning for dams and reservoirs. ${ }^{49}$

Nor is the assumption of boundaries solely true for water management. The "dynamic equilibrium" model now firmly in place in fields such as ecology is based on the assumption that although natural systems vary, the size of the range of variability experienced over long time frames in the past will continue relatively unchanged into the future. ${ }^{50}$ Although change in natural systems is inherent, it tends to be bounded within predictable confines. There is a reason why massive deluges are called a 100-year flood-we can reasonably expect such an event every century.

This "idea that natural systems fluctuate within an unchanging envelope of variability" is known in the resource- and infrastructuremanagement disciplines as the "stationarity assumption." It assumes that change can be managed within a fairly well-defined range of extremes. Water-resource managers, for example, have to accommodate change in their infrastructure planning as periods of drought and heavy precipitation come and go. Human interventions in natural systems, such as dams and dikes in the water-management context, provide further flexibility to deal with significant changes in rainfall. Thus planners "generally have considered natural change and variability to be sufficiently small to allow stationarity-based design." ${ }^{25}$ Without this assumption, which has been well justified by the historical record over relevant time frames, planners would not be

49. See generally A. DAN TARLOCK, JAMEs N. CORbridge, JR., David H. GeTChES \& ReEd D. BEnson, Water Resource Management: A CASEbook IN LAW and PubliC POLICY (6th ed. 2009) (examining the significance of variation in water supply); Milly et al., supra note 28 (challenging the continued validity of stationarity as a central assumption of water-resource planning).

50. Ecologists developing this model place less emphasis on classical conceptions of stasis and natural stability. See, e.g., Bryan Norton, Change, Constancy, and Creativity: The New Ecology and Some Old Problems, 7 DUKe ENVTL. L. \& POL'Y F. 49, 56-57 (1996); Reed F. Noss, Some Principles of Conservation Biology, as They Apply to Environmental Law, 69 CHI.KENT L. REV. 893, 893 (1994) ("Among the new paradigms in ecology, none is more revolutionary than the idea that nature is not delicately balanced in equilibrium, but rather is dynamic, often unpredictable, and perhaps even chaotic."); see also Jonathan Baert Wiener, Law and the New Ecology: Evolution, Categories, and Consequences, 22 ECOLOGY L.Q. 325, 327-28 (1995) (reviewing JoNATHAN WeINER, THE BEAK OF THE Finch: A STORY OF EVOLUTION IN OUR TIME (1994)).

51. Milly et al., supra note 28 , at 573.

52. Id. 
able to design, finance, and operate massive, capital-intensive, longterm projects on major river systems or in large agricultural districts.

But the extreme biophysical disruptions of climate change will systematically challenge the stationarity assumption across the board. As one researcher has bluntly predicted, "stationarity is dead." ${ }^{54}$ This necessarily means that planning and decision methods incorporating stationarity-based resource-management and infrastructure-design principles need to be revisited, lest they become "dead" as well. ${ }^{55}$ In 2010 , for example, the city of Seattle was planning to install a quarterbillion dollars' worth of storm drain pipes, meant to serve the city for the next seventy-five years. ${ }^{56}$ Given the realities of climate change, however, the city's planners asked a question that should have been easy to answer: What diameter should the pipes be? If the past century of rain records are no longer a useful guide for predicting storm-runoff loads, could climate models help guide the storm-drain design? ${ }^{57}$ The city's meteorologist said that he "told them I couldn't give them an answer."

The question for resource and infrastructure managers, therefore, is whether climate change will so alter natural systems as to render obsolete the assumptions of stationarity-based management and design. Many believe that planning going forward must be based on a changing climate and greater uncertainty, depending on which climate-forcing scenario seems most probable. ${ }^{59}$

53. See id. ("Stationarity ... is a foundational concept that permeates training and practice in water-resources engineering.").

54. Id.

55. See Victor B. Flatt \& Jeremy M. Tarr, Adaptation, Legal Resiliency, and the U.S. Army Corps of Engineers: Managing Water Supply in a Climate-Altered World, 89 N.C. L. REV. 1499, 1500 (2011) ("Our laws must adapt when they can no longer serve their intended function in light of a climate-altered world.").

56. Richard A. Kerr, Vital Details of Global Warming Are Eluding Forecasters, 334 SCIENCE 173, 173 (2011).

57. See Flatt \& Tarr, supra note 55 , at $1504-05$.

58. Kerr, supra note 56, at 173 ; see also Milly et al., supra note 28 , at 573-74 ("Systems for management of water throughout the developed world have been designed and operated under the assumption of stationarity."); $c f$. Richard A. Kerr, Time To Adapt to a Warming World, but Where's the Science?, 334 SCIENCE 1052, 1052 (2011) (discussing the paucity of "actionable science" upon which adaptation decisions can be made).

59. See Milly et al., supra note 28 , at 574 ("Nonstationary hydrologic variables can be modeled stochastically to describe the temporal evolution of their [probability density function], with estimates of uncertainty. Methods for estimating model parameters can be developed to combine historical and paleohydrologic measurements with projections of multiple climate models, driven by multiple climate-forcing scenarios."). 
The bottom line, however, is that the end of stationarity in biophysical systems means the end of business as usual for resource management and infrastructure planning. Does it also mean the end of business as usual for law? Perhaps so.

2. The Stationarity Assessment Model for Legal Fields. Law also depends heavily on stationarity-based design. Every field of law is embedded in assumptions about variability in natural, social, or economic conditions. The development of environmental law, for example, has embraced the "dynamic equilibrium" model of ecosystems and its assumptions about the relatively stable envelope of variability in natural systems. ${ }^{60}$ But stationarity-based design in law is not limited to fields devoted to natural systems. Family law, for example, rests upon basic social assumptions such as what constitutes a family, the responsibility of the state to protect minors, and the role of women in society. ${ }^{61}$ These assumptions have direct impacts on practical policies such as whether to allow same-sex couples to adopt, when children should be removed from the home, and the right to alimony for divorced women. As society's views have changed toward gay rights and women's rights so, too, have these new views brought fundamental changes in family law. ${ }^{62}$

Similarly, climate change will trigger potentially sweeping transformations in natural, social, and economic systems. These changes, however, will vary across the landscape and will not affect law uniformly across all fields. For example, it is difficult to think of any stationarity assumptions of family law being significantly distorted by climate change. There may be more demand for family lawyers in areas hard hit by climate change as families come under financial and personal stress, but this hardly presents a need for

60. E.g., Fred P. Bosselman \& A. Dan Tarlock, The Influence of Ecological Science on American Law: An Introduction, 69 CHI.-KENT L. REV. 847, 863-64, 868 (1994); Wiener, supra note 50 , at 333-34.

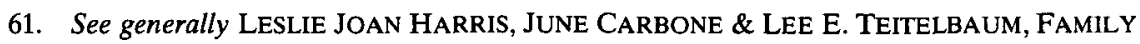
LAW (4th ed. 2010).

62. See, e.g., Judith G. McMullen, Alimony: What Social Science and Popular Culture Tell Us About Women, Guilt, and Spousal Support After Divorce, 19 DUKE J. GENDER L. \& POL'Y 41, 53-55 (2011) (exploring how the increase in working women has affected societal attitudes and by extension alimony payments to women when they divorce); Edward Stein, The "Accidental Procreation" Argument for Withholding Legal Recognition for Same-Sex Relationships, 84 CHI.-KENT L. REV. 403, 411-12 (2009) (arguing that changes in societal views about marriage and procreation have influenced court decisions regarding marriage and adoption for same-sex couples). 
family law to transform. The foundations of family law are neither built directly or indirectly on assumptions about the biophysical impacts of sea level or the timing of snowmelt, nor are they built on the related social and economic impacts of those biophysical phenomena. No surprise, therefore, that climate change adaptation has not been a hot topic in family-law scholarship. ${ }^{63}$

By contrast, some fields of law rest deeply on assumptions about variability in conditions that climate change may affect substantially. Environmental law is an obvious example, but it is not alone. Consider the age-old common-law rules of littoral-property rightshow property rights should be allocated when waters move across the land-and how those rules account for physical change in the coastal environment through doctrines such as accretion and avulsion. ${ }^{64}$ These doctrines have developed over a historic period with little variability in sea level, storm surges, storm frequency, or storm intensity. Those coastal-system attributes fluctuate over time, which is the very reason littoral-rights law developed these doctrines, but the range within which those attributes fluctuate has not deviated much for a very long time. That said, property law has never faced the prospect of the sea level rising a foot or more.

Perhaps sea-level rise will turn out to be of no consequence to the law of littoral rights, as lawyers and courts put all the existing doctrines to work to adjust for the effects as they arise. Or, perhaps, conflicts created by sea-level rise will require changes to the existing set of doctrines. Rapid sea-level rise may so distort the envelope of variability in coastal conditions that the law of littoral-property rights simply will not work anymore and a new system of rules will become necessary. Any of these paths of the law seems plausible. No surprise, therefore, that climate change has been a hot topic in littoralproperty-law scholarship. ${ }^{65}$

63. We have been unable to find legal commentary suggesting any such connections. There is no chapter on family law in any text on climate change adaptation. See, e.g., THE LAW OF ADAPTATION TO CLIMATE CHANGE: U.S. AND INTERNATIONAL ASPECTS, supra note 15.

64. See Holly Doremus, Climate Change and the Evolution of Property Rights, 1 U.C. IRVINE L. REV. 1091, 1109 (2011).

65. See generally, e.g., J. Peter Byrne, Rising Seas and Common Law Baselines: A Comment on Regulatory Takings Discourse Concerning Climate Change, 11 VT. J. ENVTL. L. 625 (2010); Doremus, supra note 64; Margaret E. Peloso \& Margaret R. Caldwell, Dynamic Property Rights: The Public Trust Doctrine and Takings in a Changing Climate, 30 STAN. ENVTL. L.J. 51 (2011); Symposium, Sea Level Rise and Property Rights, 26 J. LAND USE \& ENVTL. L. 239 (2011). 
Moving from family law and littoral rights to a more theoretical level, we argue that this kind of Stationarity Assessment can serve as a model framework for evaluating the likelihood of any new legal field emerging from significant changes to background natural, social, and economic conditions. The assessment involves a three-step inquiry:

- Step 1. What is the envelope of variability for the key natural, social, and economic attributes within which a field of law operates and on which its assumptions for theory and practice are based?

- Step 2. To what extent will forces of change distort the field's envelope of variability?

- Step 3. To what extent will the expected new variability regime require altering or abandoning the stationarity-based components of the field's theory and practice?

We readily admit that this is a simple model for a complex phenomenon, but its basic questions offer explanatory power. The model's focus ties directly back to the themes underlying the cyberspace-law debate outlined in Part I. Agents of change, in that case technological, frequently generate novel subject matter, social practice, and governance challenges, but usually these new challenges fit within the range of variability assumptions on which the relevant fields of law are based. The critics of cyberlaw-as-a-field argued this very point-that the novelties wrought by the Internet were within the comfort zone for "the fields of law tarred with the 'cyberlaw' brush: commercial law, the problems of multiple sovereignty, and a potpourri of privacy, intellectual property, and the First Amendment." ${ }^{166}$ The interstices of these existing fields, in other words, had plenty of capacity to absorb the changes. But when change begins to push legal challenges outside of the stationarity-based assumptions of relevant existing fields, one should begin to question whether the interstitial capacity is truly there. In short, novelty alone does not justify the emergence of a new legal field.

To demonstrate the Stationarity Assessment model's robustness, we apply it to two historical examples of the emergence of distinct fields of law-environmental law and environmental justice. We then apply the model to climate change adaptation and law in Part II.

66. Sommer, supra note 40 , at 1149-50. 
3. Testing the Model for Environmental Law and Environmental Justice. Few would suggest today that environmental law is an empty construct, a Law of the Horse. Quite the contrary, "in everyday discourse, the label 'environmental law' signifies a distinct and unique area of law." ${ }^{.67}$ Lawyers identify themselves (and are recognized by others) as "environmental lawyers," and those who lack this title are wary of entering the doctrinal thicket. Yet this most certainly was not the case five decades ago.

Prior to the 1970s, environmental problems had been addressed almost exclusively through common-law doctrines such as nuisance and trespass. ${ }^{68}$ There were no comprehensive environmental protection agencies, and laws directed at air and water pollution proved ineffectual.$^{69}$ More fundamentally, people did not think of air, water, and soil pollution as all parts of a larger environmental problem. This neglect started to change in the 1960 s, partly due to the acceptance of ecological thinking through the writings of Barry Commoner, Rachel Carson, Paul Ehrlich, and others who made clear to the public the connections between environmental health and our well-being. ${ }^{70}$ Part was due also to the graphic power of seeing the earth from space - a fragile orb without borders. ${ }^{71}$ And part was due to forward-thinking lawyers who created strategies to use the law for environmental protection.

As Professor Richard Lazarus has documented, at the earliest meetings to discuss legal strategies for environmental protection, the participants "deliberately resisted 'any attempt to define environmental law' and speculated that the best theory 'might well be

67. Jay D. Wexler, The (Non) Uniqueness of Environmental Law, 74 GEO. WASH. L. REV. 260,260 (2006).

68. Robert V. Percival, Christopher H. Schroeder, Alan S. Miller \& James P. Leape, EnVironmental Regulation: LAW, SCIENCE, AND POliCy 63 (6th ed. 2009); see also E. Donald Elliott, Bruce A. Ackerman \& John C. Millian, Toward a Theory of Statutory Evolution: The Federalization of Environmental Law, 1 J.L. ECON. \& ORG. 313, 315-18 (1985) (tracing the development of environmental law from common-law to public-regulatory-law models).

69. See PERCIVAL ET AL., supra note 68 , at 88-89 (recalling that nineteenth-century state and local environmental ordinances "were poorly coordinated and rarely enforced"); Elliott et al., supra note 68, at 317 ("For two centuries, the effects of industrial pollution on the natural environment had been generally free from regulation by government ....").

70. See PERCIVAL ET AL., supra note 68, at 90 (discussing examples of events that raised public concern about environmental issues).

71. See, e.g., Steve Connor, Isn't That Something, INDEPENDENT, Jan. 10, 2009, at 13 ("Earthrise, December 1968- the first picture of our world taken from space was published 40 years ago this week and still retains its haunting power. ..."). 
that there is nothing at all unique about environmental law.",72 To paraphrase Judge Easterbrook, they envisioned environmental law as a Law of the Horse. As noted before, the term "environmental law". did not even exist until 1969. ${ }^{73}$

In short order, though, a "[r]evolution in [1] aw" happened in the 1970s. ${ }^{74}$ Policymakers, lawyers, activists, and legal scholars purposively forged a distinct regime with its own statutes, institutions, and guiding principles. ${ }^{75}$ What is recognized today as the field of environmental law would not have materialized as such if these actors had instead listed all the issues concerning the environment and divvied them up to existing fields of practice and policy.

How well does the Stationarity Assessment model explain this history? The first step is to identify the envelope of variability on which the field's assumptions are based. As noted above, prior to the 1970s the bulk of pollution control was handled through the common law, particularly through nuisance doctrine. ${ }^{76}$ Nuisance law worked well so long as pollution conflicts were local, the causes and effects straightforward, and remedies simple to design and administer. ${ }^{7} \mathrm{By}$

72. LAZARUS, supra note 22 , at 48 .

73. Id. at 47 .

74. See id. at 67-97.

75. In his sweeping assessment of the origins and coherence of environmental law as a field, Professor Tarlock recounts the audacity of the field's early visionaries:

What we now call environmental law is very much embedded in the legal landscape. The area has developed in an astonishingly short period of time as a result of the rise of environmentalism as a political force in the late 1960s. The field was created virtually out of whole cloth by a receptive Judiciary and Congress. In the 1960s, environmental protection was a marginal political idea. Lawyers followed the great common law tradition left open to socially marginal groups and pursued a "rule of law litigation" strategy. To discipline public agencies through what we now call "public interest" litigation, they had to convince courts that something called environmental law existed, when in fact it did not. Creative lawyers used a few meager precedents and vague, seldom applied statutes to convince courts that public agencies had a duty to consider "environmental" interests and to take steps to avoid or mitigate adverse "environmental" impacts. Lawyers skillfully created the fiction that the recognition of new environmental protection duties merely required courts to perform their traditional and constitutionally legitimate function of applying and enforcing, rather than creating, pre-existing rules.

A. Dan Tarlock, Is There a There There in Environmental Law?, 19 J. LAND USE \& ENVTL. L. 213, 215-16 (2004) (footnotes omitted).

76. See supra Part I.B.2.

77. As one leading property-law casebook observes, for example, "nuisance litigation is illsuited to other than small-scale, incidental, localized, scientifically uncomplicated pollution problems." Jesse DUKEMINIER, JAMEs E. KRIER, GREgORY S. AlEXANDER \& MiCHAEL H. SCHILL, PROPERTY 759 (7th ed. 2010); see also PERCIVAL ET AL., supra note 68, at 75 ("When numerous and diverse pollutants emanating from widely dispersed sources affect large populations, the common law is a poor vehicle for providing redress ...."). 
the late 1960s, however, it was clear that pollution conflicts had gone beyond the assumptions about the envelope of variability for scale and complexity. Modern environmental problems were by then "typified . . . by continuing and multiple causes, widespread effects and multiple victims, and scientifically complex issues as to cause, effect, and remedy." ${ }^{, 8}$

Could nuisance law respond to this expanded envelope of variability in scale and complexity-could it effectively manage modern pollution problems as a tort? The law might have adapted through innovations in class actions, attorneys' fees for plaintiffs suing "in the public interest," environmental courts, and similar incremental changes. ${ }^{79}$ But the strong sense was that this internal adaptive approach would not suffice-a transformation was needed that would shift pollution problems from the common law to public regulatory law. As Professor Lazarus has described, the "essential premise of much environmental law is . . . that the physical characteristics of the ecosystem generate spatial and temporal spillovers that require restrictions on the private use of natural resources far beyond those contemplated by centuries-old common law tort rules." ${ }^{\text {80 }}$

This transition was spelled out in the famous case of Boomer $v$. Atlantic Cement Co. ${ }^{81}$ in which New York's highest court declined to enjoin a cement plant's air emissions found to constitute a nuisance, ruling instead that a damages remedy, previously not available under New York law, was the more efficient approach. ${ }^{82}$ Though the case is known mostly for its shift in nuisance remedial doctrine (clear evidence of the need for adaptation), the court's rationale for backing off injunctive relief sent a loud message to courts and legislatures that a transformative approach ultimately would be necessary. As the court warned in its timely decision from 1970:

It seems apparent that the amelioration of air pollution will depend on technical research in great depth; on a carefully balanced consideration of the economic impact of close regulation; and of the actual effect on public health. It is likely to require massive public

\footnotetext{
78. DUKEMINIER ET AL., supra note 77 , at 759.

79. Id.

80. LAZARUS, supra note 22, at 121.

81. Boomer v. Atl. Cement Co., 257 N.E.2d 870 (N.Y. 1970).

82. Id. at 875 .
} 
expenditure and to demand more than any local community can accomplish and to depend on regional and interstate controls.

A court should not try to do this on its own as a by-product of private litigation .... This is an area beyond the circumference of one private lawsuit. It is a direct responsibility for government and should not thus be undertaken as an incident to solving a dispute between property owners... ${ }^{83}$

The date of the opinion, not coincidentally, marks the advent of the modern era of environmental law and of the wave of federal legislation regulating air, water, and land pollution. The court argued that reliance on private nuisance actions would be "grossly inadequate for resolving the more typical pollution problems faced by modern industrialized societies." ${ }^{\text {s4 }}$ Add to this the poor fit between nuisance law and the rising tide of environmental values reflected in natural-resource management such as endangered species, loss of wetlands, biodiversity conservation, and predecision impact assessment, and it is no surprise that nuisance law gave way to the modern environmental law regime, as the Stationarity Assessment model predicts it would.

We can trace a more recent history through the formation of the field of environmental justice. During the explosion of environmental laws in the 1970s, the focus had been on reducing aggregate pollution levels. Little or no thought was given to the distributional impacts of environmental protection. ${ }^{85}$ This began to change in the early $1980 \mathrm{~s}$

83. Id. at 871 .

84. PERCIVAL ET AL., supra note 68 , at 75 . The common law simply could not handle the new expanded stationarity regime of the modern pollution problem, "which is why environmental law evolved beyond those principles to fill the gap with detailed standards and regulatory controls." LAZARUS, supra note 22 , at 134 . There is continued debate, however, over whether the common law is this ineffective as a mechanism for controlling pollution. For a collection of articles debating the point, see generally Symposium, Common Law Environmental Protection, 58 CASE W. RES. L. REV. 575 (2008).

85. As an illustrative example, in 1971 the Sierra Club surveyed its members on their interest in having the Club address social-justice issues. "When asked, forty-one percent of the members 'strongly disagreed' with the statement that the Club should 'actively involve itself in the conservation problems of such special groups as the urban poor and the ethnic minorities."' Alice Kaswan, Environmental Justice: Bridging the Gap Between Environmental Laws and "Iustice," 47 AM. U. L. REV. 221, 262 (1997) (quoting the Sierra Club survey); see also Richard J. Lazarus, Pursuing "Environmental Justice": The Distributional Effects of Environmental Protection, 87 Nw. U. L. REV. 787, 788 (1993) ("Largely ignored in the celebration that accompanied the passage of a series of ambitious environmental protection laws during [the 1970s] were those distinct voices within minority communities that questioned the value of environmentalism to their communities."). 
with, in particular, high-profile opposition by an African-American community in North Carolina to a hazardous waste landfill sited for Warren County. ${ }^{86}$

A series of studies by the United Church of Christ's Commission for Racial Justice and the U.S. General Accounting Office found strong correlations between communities' racial and economic characteristics and their proximity to hazardous-waste landfills. ${ }^{87}$ Further studies reached similar conclusions-locally undesirable land uses were disproportionately located near minority or low-income communities. ${ }^{88}$ Correlations were ultimately shown for exposure to air pollution, lead poisoning, pesticides, occupational hazards, and both the stringency and speed of enforcement actions. ${ }^{89}$

It is important to recognize that, prior to the late $1980 \mathrm{~s}$, the term "environmental justice" did not exist. By 1990, though, the U.S. Environmental Protection Agency (EPA) had created the Environmental Equity Workgroup to examine the distributional issues raised by environmental policies and enforcement. ${ }^{90}$ In 1994, the Clinton administration issued an Executive Order directed at federal actions and environmental justice. ${ }^{91}$ Today, considering the distributional impacts of environmental protection has become commonplace.

One might conclude from its name that environmental justice is an integral component of environmental law. In fact, however, it largely operates from the outside-it arose to police environmental policy and to ensure the just distribution of benefits and burdens-

86. See J.B. Ruhl, John Copeland Nagle, James Salzman \& Alexandra B. Klass, THE PRACTICE AND POLICY OF ENVIRONMENTAL LAW 25 (2d ed. 2010).

87. Id.

88. Id.

89. Id.

90. Environmental Justice: Basic Information, U.S. ENVTL. PROT. AGENCY, http:/www.epa.gov/environmentaljustice/basics/ejbackground.html (last visited Jan. 17, 2013).

91. Federal Actions To Address Environmental Justice in Minority Populations and LowIncome Populations, Exec. Order No. 12,898, 3 C.F.R. 859 (1995), reprinted as amended in 42 U.S.C. $\$ 4321$ (1994 \& Supp. V 1998). This order creates an interagency working group from the heads of many agencies and departments. Id. $\S 1-102$. They are charged to provide guidance for identifying regulations that produce disproportionate impacts on the health or environmental quality for minority or low-income populations. Id. \$\$ 1-102 to -103 . Agencies are also charged to come up with plans for avoiding such impacts. Id. $\S 1-103$. As with all executive orders, this creates no rights enforceable in a court of law. $I d$. $\S 6-609$. 
and thus has not been assimilated within environmental statutes. ${ }^{92}$ Unlike the Clean Air Act $^{93}$ or Clean Water Act, ${ }^{94}$ there is no single "Environmental Justice Act." Instead, over time, environmental justice has grown into an overarching field of law and policy, examining decisions made in many fields including environmental, land use, and urban development and expressed in the law through executive orders, administrative guidance, and agency licensing and permitting procedures. ${ }^{95}$

How well does the Stationarity Assessment model explain this history? The basic assumption (Step 1) throughout the 1970s' creation of modern environmental law had been that the new statutes either had no distributional inequities or were irrelevant. Protests over siting decisions and studies of the demographics of locally undesirable land uses starting in the $1980 \mathrm{~s}$, however, demonstrated that these were false assumptions. ${ }^{96}$ The assumed envelope of variability-that environmental law did not need to concern itself with distributional impacts-was blown apart (Step 2). In time, it became apparent that a new field of environmental justice was necessary (Step 3) because environmental law had not been designed to be self-aware or self-

92. As Professors Verchick and Hall explain,

[A] specific charge to pursue environmental justice is all but nonexistent in the nation's vast armada of federal environmental statutes. It's not that our environmental statutes reject environmental justice, or that they are necessarily inconsistent with it (although some have considered the point). Rather, the laws were not developed with this priority in mind.

Robert R.M. Verchick \& Abby Hall, Adapting to Climate Change While Planning for Disaster: Footholds, Rope Lines, and the lowa Floods, 2011 BYU L. REV. 2203, 2224-25 (footnotes omitted).

93. Clean Air Act, Pub. L. No. 91-604, 84 Stat. 1676 (1970) (codified as amended at 42 U.S.C. $\$$ 7401-7671q (2006 \& Supp. IV 2011)).

94. Clean Water Act, Pub. L. No. 92-500, 86 Stat. 816 (1972) (codified as amended at 33 U.S.C. §§ 1251-1387 (2006 \& Supp. IV 2011)).

95. For a broad overview of environmental justice law in its present forms, see generally U.S. ENVTL. PROT. AGENCY, Plan EJ 2014: Legal TOOLS (2012), available at http://www.epa.gov/environmentaljustice/resources/policy/plan-ej-2014/ej-legal-tools.pdf.

96. See UNITED CHURCH OF CHRIST JUSTICE \& WitNesS MinistRIES, TOXIC WASTES AND RACE AT TWENTY: 1987-2007, at 1 (2007), available at http://www.ucc.org/justice/ pdfs/toxic20.pdf (stating that protests objecting to the racially inequitable Warren County waste site were the initial catalyst for creating a report on environmental justice); see also LUKE W. COle \& SHeila R. Foster, From the Ground Up: EnVironmental Racism and THE Rise OF THE ENVIRONMENTAL Justice MOVEMENT 54-55 (2000) ("Since the 1960s, researchers have analyzed the distribution of numerous environmental hazards: garbage dumps, air pollution, lead poisoning, toxic waste production and disposal, pesticide poisoning, noise pollution, occupational hazards, and rat bites. Their overwhelming conclusion is that these environmental hazards are inequitably distributed by income or race."). 
policing for distributional impacts, nor could it be trusted to do so fairly. The field that has emerged is quite different from most environmental law-more procedural than substantive, more a framework of analytical questions than of command-and-control statutory provisions.

By contrast, consider the more relevant example of oceanmanagement policy. At the domestic level, this also operates as a Law of the Horse, but everyone recognizes that is suboptimal. In recent years, two blue-ribbon commissions on ocean policy have both demonstrated that ocean ecosystems are suffering under a combination of threats that require more focused legal and policy attention. ${ }^{97}$ Steps 1 and 2 of the Stationarity Assessment model have been triggered, but altering or abandoning the current structure for a more holistic legal structure has not happened, and likely will not happen, because the legal regime has become too entrenched to shift. ${ }^{98}$

It may prove infeasible to forge a new field of climate adaptation law. Mindful of the oceans example, though, it would be unwise not to consider at an early point in the development of climate adaptation policy how the law should evolve. The remainder of this Article is dedicated to this consideration.

\section{StationaRity AsSESSMENT OF Climate Change AND LAW}

Although we are the first to propose using the Stationarity Assessment model as a method for evaluating the impacts of climate change on law, other scholars have already been asking some of the same questions that the model incorporates. ${ }^{99}$ These inquiries have ranged from focused studies of fields, such as water law, resourceconservation law, and human rights law, ${ }^{100}$ to broader expositions on climate change adaptation as an agent of legal change in areas such as

97. See Studley, supra note 25 , at 109-13 (detailing the creation of ocean-policy commissions by both the Bush and Obama administrations).

98. It is interesting to note that law for horses never progressed beyond Steps 1 and 2 . Assumptions about horses and their activities have not changed, so the pressures for a new field have never coalesced. No one is heard demanding the creation of a distinct field of horse law to manage all of the legal issues having to do with horses. Law for horses remains a Law of the Horse.

99. See, e.g., Craig, supra note 6, at 16-18 (responding to questions regarding whether the stationarity model is an accurate and effective assumption in the face of changed conditions resulting from climate change and suggesting what an alternative model should look like).

100. See supra note 6. 
federalism. ${ }^{101}$ These studies also have produced a range of conclusions, from predictions that different fields of law can evolve to accommodate climate change impacts, ${ }^{102}$ to concerns that the distortion of stationarity assumptions will be so profound as to demand revolutionary changes across crosscutting swaths of law. ${ }^{103}$ To evaluate those conclusions, we present a case study of climate change adaptation in a coastal region. We then step back to assess what this suggests for the development and organization of climate change law and policy.

\section{A. Stationarity Assessment Case Study}

The biophysical effects of increasing atmospheric greenhouse-gas concentrations will be uneven around the globe and within the United States. ${ }^{104}$ The principal impacts and their core set of environmental consequences are well understood-rising mean surface temperature, ocean acidification and warming, rising sea level, and changes in precipitation patterns. ${ }^{105}$ Many biophysical consequences of these primary drivers are also well understood, such as changes in the variability and intensity of storm events, migration of species to adjust to changed conditions, changes in flood and drought patterns, and shifts in ecosystem regimes. ${ }^{106}$ Nonetheless, the socioeconomic impacts of climate change and the adaptation responses needed to manage them are difficult to anticipate at local scales. Climate change researchers have constructed rough scenarios for many regions, however, and cities and states are beginning to develop adaptationplanning processes. ${ }^{107}$ Synthesizing from that body of work, we

101. See, e.g., Ruhl, supra note 6, at 391-432.

102. See J. Peter Byrne, The Cathedral Engulfed: Sea Level Rise, Property Rights, and Time, 73 LA. L. REV. 69 (2012) (exploring likely evolutions in property law in response to sea-level rise); J.B. Ruhl, Climate Change and the Endangered Species Act: Building Bridges to the NoAnalog Future, 88 B.U. L. REV. 1, 59-62 (2008) (suggesting several ways that the existing endangered-species regime can meet its goals in the face of climate change).

103. See supra notes $16-18$ and accompanying text.

104. See generally InTERgovernmental PANEL ON Climate CHANGE, supra note 2; U.S. Global CHANGE Research PROGRAM, supra note 2.

105. Cf. U.S. Global Change ResearCh Program, supra note 2, at 17-40 (explaining various phenomena associated with climate change and their predicted environmental impacts).

106. Cf. id. at 41-106 (explaining some of the effects of climate change on ecosystems).

107. See Vicki Arroyo \& Terri Cruce, State and Local Adaptation, in THE LAw of ADAPTATION TO Climate CHANGE: U.S. AND INTERNATIONAL ASPECTS, supra note 15, at 569 (stating that state and local leaders are taking action to adapt to changing climatic conditions based on regional predictions of climate change effects). 
develop a plausible local climate change scenario here to apply the Stationarity Assessment model in a dynamic legal adaptation context.

Drawing from a number of assessments of climate change impacts, ${ }^{108}$ our case study focuses on a hypothetical coastal city in the United States and its adjoining rural areas. The region enjoys a classic four-season climate and all of the recreational activities such a climate makes possible. The city has a thriving harbor area and busy waterfront business and entertainment districts. Local surface reservoirs and groundwater aquifers provide ample water for residential and commercial uses. Not far from the city along the coast is a large wildlife-refuge area rich in coastal estuarine wetlands and an abundance of waterfowl. A significant fishery industry operates just offshore. Inland of the city one finds a large agricultural district. The farms raise a variety of crops and livestock and have ample water supply from natural precipitation combined with water withdrawals from rivers augmented by snowmelt runoff from a nearby mountain region. Abundant public parks provide recreational opportunities. In general, life is good in this corner of the world.

What will happen to our idyllic coastal region as climate change continues on its present course? Assume that in this region surface temperatures continue rising, the sea level continues rising, and overall precipitation levels fall but intense precipitation events become more common. To put pressure on the legal system for purposes of our Stationarity Assessment, a plausible worst-case scenario of biophysical and socioeconomic changes and likely adaptive responses can be constructed around the region's various sectors.

Urban: The central city, focused on its harbor economy and thriving commercial districts, faces the dire threats of rising sea levels and more frequent and intense storm events. These effects will threaten the integrity of the waterfront infrastructure and buildings and pose increased flooding risks to the central city as a whole. Rising

108. We have synthesized our case study from analyses provided in several leading national and state impact-assessment and adaptation-planning studies. See generally CAL. NATURAL RES. AGENCY, supra note 5; GOVERNOR's ClimATE CHANGE INTEGRATION GRP., FINAL REPORT TO THE GOVERNOR: A FRAMEWORK FOR ADDRESSING RAPID CLIMATE CHANGE (2008), available at http://www.oregon.gov/ENERGY/GBLWRM/docs/CCIGReport08Web.pdf; Mass. Exec. OfFice of ENERgy \& ENVTl. AfFairs, MassachusetTs Climate Change ADAPTATION REPORT (2011), available at http://www.mass.gov/eea/docs/eea/energy/cca/eeaclimate-adaptation-report.pdf; U.S. GLOBAL CHANGE RESEARCH PROGRAM, supra note 2. Our goal is not to document a particular climate change outcome, but rather to construct a plausible regional scenario from which to assess legal adaptation. 
temperatures will lead to increased demand for cooling of buildings and cars in warm seasons, though heating demand will fall in cooler seasons. More frequent heat waves will threaten sensitive populations, though fewer intense cold snaps will alleviate a different source of health concerns. Increased temperatures could also allow introduction of disease-bearing insects and other vectors. Reduced overall precipitation will decrease reservoir supplies, and sea-level rise will pose the risk of saltwater intrusion to water supply aquifers. Depending on relative conditions in other urban areas, climateinduced human migration may lead to substantial positive or negative population shifts.

Possible adaptive responses to these changed conditions include a wide range of approaches. Sea-level rise and storm-surge events could be combated through the construction of seawalls and other water-barrier structures, or the waterfront infrastructure could be abandoned and replaced further inland in protected areas. Rising energy demands in warm seasons likely will lead to efforts to increase peak energy capacity as well as to develop new production technologies and conservation methods. Health concerns associated with heat and disease will require increased public-health capacities. Decreasing water supplies will demand more effective waterconservation methods and put pressure on local authorities to locate new sources of water.

Agricultural: Warming temperatures will increase the length of growing seasons, but may also introduce new agricultural crop pests, weeds, and livestock diseases. Some crops and livestock will not tolerate the new temperature regime, but farmers may be able to replace them with other suitable varieties. Rising temperatures will also reduce precipitation in the mountain region and cause earlier snowmelt events, thus altering the availability of irrigation water from the region's rivers. Reduced overall precipitation also will strain water availability, threatening the viability of some crops and livestock. Increased frequency and intensity of storm events will lead to increases in crop damage and soil erosion.

Farmers will adapt to these changes by switching to different crop varieties and, with more difficulty, different livestock. Improved farming methods could enhance water-use efficiency and protect crops from storm events. New crops, pests, and weeds may prompt farmers to use different fertilizers, insecticides, and herbicides. As with urban water users, decreased agricultural water supplies also will put pressure on farmers to secure new supplies. 
Coastal and Marine: Rising sea levels will erode shorelines and inundate existing coastal wetlands, though in some places existing upland areas will transition into new wetland regimes. Increased frequency and intensity of storm events will further damage coastal wetlands and pose flooding risks to coastal properties. Rising ocean temperatures will affect the viability of valuable fishery species and allow for the introduction of invasive species and disease-bearing species. Increasing carbon dioxide concentrations will acidify marine ecosystems, threatening the integrity of coral reef systems that provide storm surge protection to coastal lands. Earlier snowmelt events and more frequent and intense storm events will alter the flow pattern of nutrients from inland regions to the marine environment.

Although some of the adaptive responses for rural coastal lands will be similar to those available to the urban area, resources may be more limited, and thus options such as seawalls and offshore barriers may be less viable. The fishery industry will have little power over changes to the local marine species assembly, and thus will be forced to switch catch targets, to move to other fishing grounds, or to shut down.

Recreation: Rising temperatures will reduce cold-weather recreation opportunities while increasing the length of the warmweather recreation season. Increased frequency of heat waves and storm events, however, will limit warm weather recreation days. Decreased overall precipitation will limit water-related recreation such as freshwater boating and skiing in the mountains. Increased water temperatures could reduce some freshwater recreational opportunities, such as fishing for a particular species no longer able to survive in local lakes and rivers. Rising sea levels will inundate the wildlife refuge wetlands, thus reducing waterfowl populations and any hunting opportunities associated with them.

Although economically disruptive, recreational providers should be able to transition to take advantage of the increased warm-season opportunities while phasing down in the cold season. Ski areas may no longer be viable in the mountain region, but the warm-weatherrecreation industry in the mountains and along the coast may be significantly enhanced. The hunting and fishing industries will also need to adjust to new species and habitat regimes. Public recreation areas such as the refuge and parks may need to alter infrastructure and staffing to adjust as well. Overall, however, while recreational opportunities will change, they will remain abundant and varied. 
Ecosystems: Many species with life patterns keyed to particular temperature, precipitation, and habitat regimes may find the region's new set of conditions unsuitable. Some of those species will migrate, while those unable to migrate will face increasing stress. Other species more suited to the new set of conditions will thrive, however, and some species not previously found in the region will migrate to it. Increasing temperatures and decreasing precipitation will combine to cause more fire events. At a more fundamental level, basic ecosystem processes such as nutrient cycling and decomposition will be altered. Some ecosystems, faced with all of these threats, will transition into entirely different regimes supporting significantly altered species assemblies and providing altered streams of ecosystem services to human populations.

Ecosystem-resource managers will have difficulty adapting to these effects if their goal is to maintain a prescribed set of ecosystem conditions, as may be the case for the wildlife refuge or a wilderness area. It would be futile, for example, to attempt to halt the outmigration of species, and it would be a resource-intensive challenge to attempt to barricade ecosystems against in-migration. Even more challenging would be efforts to keep basic ecosystem processes unchanged. Preservation, in other words, will become an increasingly unattainable management goal, meaning that adaptive responses must focus on transition goals such as maintaining overall biodiversity or overall ecosystem service benefits.

This collection of scenarios is, admittedly, rather grim. But it is based on entirely plausible assumptions about climate change and its worst biophysical and socioeconomic impacts. To be sure, many other sets of plausible assumptions exist with less dire consequences, ${ }^{109}$ but our intention is to explore the strongest possible case for transformative legal change.

\section{B. Assessment of Legal Fields}

Climate change adaptation inevitably will demand the services of law and legal institutions, but that does not necessarily lead to the demand for changes in the law. The Stationarity Assessment model identifies one potential source of demand for legal transformationsignificant disruption of the law's assumptions about physical, social, and economic conditions. Professor Holly Doremus, for example, has

109. See J.B. Ruhl, The Political Economy of Climate Change Winners, 97 MINN. L. REV. $206,217-41$ (2012) (reviewing the range of climate change harms and benefits). 
suggested that because "[c]limate change will unsettle expectations about both land and water," it follows that "[c]hanges to underlying property rights will be needed." 110

As we described in the Introduction, the demands of climate change adaptation will implicate different fields of law differently. Family law jumps out as a legal field that appears to be relatively untouched by climate change. We have not rigged our case study to work family law out of the picture. One would have to contrive a farfetched story to identify novel legal issues that climate change could present for family law-indeed, we cannot think of one and have found no evidence anyone else has. But family law is not alone in this respect. Other fields of law similarly untouched include criminal law, commercial transactions, consumer law, products liability law, tax law, banking and finance law, constitutional law, administrative law, telecommunications law, and food and drug law, to name just a few.

Take any of these fields and work it through the Stationarity Assessment model. We will use criminal law as an example. It is difficult to articulate any assumption that criminal law makes about the variability of natural, social, or economic conditions that will be disrupted in any substantial sense by climate change. Perhaps certain kinds of crime, such as looting, are associated with natural events such as hurricanes and floods. Yet how criminal law manages such crimes is in no sense based on assumptions about the range of variability of hurricanes and floods. To the extent that any adjustments are needed by the legal system to respond to novel crimes associated with the effects of climate change, criminal law will adapt to manage them.

To be sure, climate change adaptation will be a medium within which legal issues in criminal law and many other fields arise-one can envision crimes involving bid-rigging for sea-wall construction, intellectual property issues involving patents for new weatherproofing technologies, and products liability issues involving climate adaptation products. But those circumstances present no pressure for the law to adapt any more than do bid-rigging for subway construction, a patent for a new electronic device, or an injury from a defective kitchen product. They are simply new fact patterns to plug into the existing legal doctrine and practice. In all such cases the Stationarity Assessment comes up negative-to the extent these fields

110. Doremus, supra note 64, at 1091. 
of law make any assumptions about the range of variability for conditions likely to be affected by climate change, novel legal issues arising from climate change will fit within their interstices.

At the opposite end of the spectrum are fields such as water law that are likely to confront sets of conditions with no, or at best weak, analogs in existing doctrine and practice. Water-law scholars, for example, have argued that their field faces tremendous pressure to change in response to climate change, and our case study offers no reason to doubt them. ${ }^{111}$ The changes in precipitation patterns and the availability of the right quality and quantity of water could thrust the agricultural and urban populations into a water competition like none they have experienced. Indeed, the region as a whole may find itself competing with other regions for new supplies and negotiating with yet other regions-regions suddenly in water abundance-for water transfers.

What makes family law and water law so different in this respect? We believe the answer lies in their respective stationarity assumptions. Water law is, at bottom, about water scarcity, and the natural-water system is in store for a tremendous amount of change. Family law, by contrast, is not about a biophysical system. Nor are the other fields in the long list suggested previously. The legal fields most exposed to adaptive pressures from climate change, in other words,

111. A growing number of water-law scholars have argued that climate change adaptation will demand fundamental reforms of domestic water-allocation law and water-property rights. See generally, e.g., Robert W. Adler, Balancing Compassion and Risk in Climate Change Adaptation: U.S. Water, Drought, and Agricultural Law, 64 FLA. L. REV. 201 (2012) (examining the complex tradeoffs between compensation, risk allocation, and risk reduction as adaptation strategies for agricultural regions where more severe drought regimes are expected); Adell Amos, Freshwater Conservation in the Context of Energy and Climate Policy: Assessing Progress and Identifying Challenges in Oregon and the Western United States, 12 U. DENV. WATER L. REV. 1 (2008); John T. Andrews, Jessica Roberts Pearson \& John K. Woodling, California Water Management: Subject to Change, 14 HASTINGS W.-NW. J. ENVTL. L. \& POL'Y 1463 (2008); Robin Kundis Craig, Adapting Water Law to Public Necessity: Reframing Climate Change as Emergency Response and Preparedness, 11 VT. J. ENVTL. L. 709 (2010); Joseph W. Dellapenna, Climate Disruption, the Washington Consensus, and Water Law Reform, 81 TEMP. L. REV. 383 (2008); Holly Doremus \& Michael Hanemann, The Challenges of Dynamic Water Management in the American West, 26 UCLA J. ENVTL. L. \& POL'Y 55 (2007); Brian E. Gray, Global Climate Change: Water Supply Risks and Water Management Opportunities, 14 HASTINGS W.-NW. J. ENVTL. L. \& POL'Y 1453 (2008); Noah D. Hall, Bret B. Stuntz \& Robert H. Abrams, Climate Change and Freshwater Resources, NAT. RESOURCES \& ENV'T, Winter 2008, at 30; Kathleen A. Miller, Climate Change and Water in the West: Complexities, Uncertainties and Strategies for Adaptation, 27 J. LAND RESOURCES \& ENVTL. L. 87 (2007); A. Dan Tarlock, Water Law Reform in West Virginia: The Broader Context, 106 W. VA. L. REV. 495 (2004). 
are those resting deeply on stationarity assumptions about biophysical systems. In addition to environmental law and water law, land use law, agricultural law, insurance law, and littoral-property rights easily come to mind as fields heavily dependent on assumptions about how the biophysical world works and, most critically, about its envelopes of variability. Rock that world and you could rock those fields of law.

Consider, for example, ways in which each of the following fields could be significantly disrupted in our coastal region case study:

- Environmental Law. Ecological change could render meaningless habitat protections for species and management goals for wildlife refuges.

- Water Law. Extreme shifts in water supplies could undermine long-standing prior appropriation water law doctrines.

- Land Use Law. Sea-level rise could lead to demands for intense restriction of coastal development and for shifting development priorities to rural inland areas.

- Agricultural Law. Farms may demand greater flexibility in their use of chemicals through changes to pesticide laws.

- Insurance Law. Questions may arise about coverage of damages from climate related events and the adequacy of insureds' adaptive measures.

- Littoral-Property Rights. Sea-level rise may present difficult legal issues about the public-private ownership divide along the coast.

Of course, change is an inherent factor in all of these fields: humans have altered ecosystems through agriculture for millennia, droughts and floods affect water supplies, development patterns shift with changes in technology, new pests arrive in agricultural districts, contaminated soil presents new issues for insurance law, and coastlines have long shifted around. But climate change is different, very different, in both the quantity and quality of change likely to be introduced into biophysical systems. Hurricanes hit the coast, and tides shift where the beach ends, but an extra foot of sea level and ten more hurricanes a year could put a coastal system well outside its historic range of variability.

What does that mean for fields intimately connected with biophysical conditions? It is tempting to move quickly to the conclusion that such fields necessarily will have to adapt to the changes in natural systems, but the Stationarity Assessment model 
demands a more deliberate analysis. It is not enough to observe that nature will change; one also has to evaluate how much variability in nature these fields of law are designed to tolerate. Given the natural range of variability even without climate change, fields like environmental law are accustomed to dramatic swings of doctrinal and institutional change.

Indeed, the history of environmental law is largely one of continuous change to adapt to changes in its physical and social contexts. For example, by the mid-1990s-just two decades into the life of modern environmental law-lawyers broadly discussed the development of "second generation" approaches to manage the widening and ever-changing array of environmental problems. ${ }^{112}$ Similarly, change in water law, even radical change, is nothing new. The classic laws of appropriative rights in the West and of riparian rights in the East have undergone significant evolution in many states over time to reflect social and economic change. ${ }^{113}$ Yet with all of these changes, environmental law is still environmental law, and water law is still water law.

Let us dig deeper into environmental law to drive this point home. What is it about climate change that is going to throw environmental law something it has never seen, something completely outside the box, something it just cannot handle? We think the answer is, nothing. To be sure, climate change will change the environment in many ways: sea-level rise will inundate coastal wetlands and erode beaches, fire regimes will change, some areas will have more water and some less, species will migrate, people will migrate, it will grow warmer everywhere. But so what? In particular, so what for environmental law? Environmental law has been operating for decades in all of those contexts. It is not as if the loss of

112. By the mid-1990s "virtually everyone ... agree[d] that our historical command-andcontrol approach [was] inefficient and inadequate by itself to carry us where we still need to go." Barton H. Thompson, Jr., Foreword, The Search for Regulatory Alternatives, 15 STAN. ENVTL. L.J. viii, viii (1996). For the leading contemporaneous accounts of the emergence of the second generation alternatives, see generally Dennis Hirsch, Second Generation Policy and the New Economy, 29 CAP. U. L. REV. 1 (2001); Richard B. Stewart, Administrative Law in the Twenty-First Century, 78 N.Y.U. L. REV. 437 (2003); and Richard B. Stewart, A New Generation of Environmental Regulation?, 29 CAP. U. L. REV. 21 (2001).

113. See generally Joseph Dellapenna, Adapting Riparian Rights to the Twenty-First Century, 106 W. VA. L. REV. 539 (2004); Joseph Dellapenna, The Law of Water Allocation in the Southeastern States at the Opening of the Twenty-First Century, 25 U. ARK. LITTLE ROCK L. REV. 9 (2002); A. Dan Tarlock, The Future of Prior Appropriation in the New West, 41 NAT. RESOURCES J. 769 (2002). 
wetlands, erosion of beaches, fire or its absence, wet or dry areas, invasive species, people moving around, and it being hot outside are anything new to environmental law. It is more likely that peoples' priorities may change and environmental law's position at the table of policymaking may grow more or less important, ${ }^{114}$ but it will still be environmental law. Consider how each of the six fields of law mentioned above could adapt to biophysical change and still retain its basic form and substance:

- Environmental law. Conservation areas can adopt new, more fluid management goals, such as managing for overall biodiversity rather than for specific biomes or species.

- Water law. The doctrine can incorporate specialized rules for extreme periods of drought and for accommodating innovations such as water markets.

- Land use law. State and local authorities can adopt specialized rules for areas threatened most by sea-level rise and embed them within existing zoning- and growth-management regimes.

- Agricultural law. With assistance from and monitoring by federal and state agencies, farms in climate-transition zones can carefully shift to new practices.

- Insurance law. Coverage issues can be worked out through gradual industry refinements to and judicial interpretations of coverage policies.

- Littoral-property rights. State courts and legislatures can adopt specialized rules of littoral property that resolve sea-level-rise issues while fitting within the broader existing regime of littoral rights.

With or without climate change, in other words, fields like these are inherently dynamic, and all indications are that change remains in their future. This is not to say that change comes easily to these fields. Often it is tumultuous and controversial. But change does come naturally to them-they are designed to change. They transform, but they do not crumble.

114. See Ruhl, supra note 6 (examining how public demand for adaptation measures such as water supply and protection from more intense storm, drought, and fire events could diminish the priority for environmental protection) 


\section{Calling a Horse a Horse}

Put simply, when one steps back and applies the Stationarity Assessment model to evaluate likely implications of climate change adaptation to the full span of legal fields, it is difficult to identify more than a few that will face pressure to change. The legal response to climate change adaptation will be evolutionary rather than revolutionary for the vast majority of legal fields. Most of law and legal institutions will see climate change adaptation as just another set of challenging issues to work through the system, and it will be easy work at that.

The short list of fields mentioned above, all sharing the common trait of resting deeply on assumptions about the stationarity of biophysical system variability, will have to work harder, maybe much harder, to adapt, and one or two might buckle under the pressure and go through transformational change. But this is far from certain. After all, land use law has imposed sharp restrictions on development in many other contexts, such as restrictions against (or mandating) the use or density of buildings in certain areas to serve a broad variety of public purposes. ${ }^{115}$ Climate change adaptation would just be a new purpose. And environmental law has already begun adapting through specialized doctrines. Thus the Endangered Species Act ${ }^{116}$ has addressed species threatened by climate change (for example, the polar bear) and appears capable of responding to climate impacts without need of sweeping doctrinal change. ${ }^{117}$ There is no reason to assume the core legal doctrines and practices of either of these fields or the others mentioned above will require sweeping transformation as the impacts of climate change become more severe.

Overall, therefore, a field-specific assessment of climate impacts suggests that climate change adaptation may well follow the path of the Law of the Horse. Specific fields will adapt on their own as challenges arise, with no need for a new field. Calling it climate adaptation law might make it suitable for a "law and" seminar in law schools or conference for practitioners, but not as a distinctly coherent operating field of law. Although this might be the most probable trajectory, however, it is not at all clear this would be the most desirable course of development. In Parts III and IV of this

115. See David L. Callies, Robert H. Freilich \& Thomas E. Roberts, Cases and MATERIALS ON LAND USE 69-133 (5th ed. 2008).

116. Endangered Species Act, 16 U.S.C. 88 1531-1544 (2006 \& Supp. V 2012).

117. See supra note 102. 
Article, therefore, we evaluate the possibility and the potential contours of forging a distinct field of climate adaptation law.

\section{JUSTIFYING AN INTERVENTION}

The preceding analysis suggests that the disruptive effects of adapting to climate change are unlikely to undermine the doctrinal substance and institutional architecture of most legal fields. The possible exceptions include those fields that depend heavily on biophysical assumptions, and even for them it is not clear that fundamental transformations will be necessary. The implication is that a new field of climate adaptation law and policy is unlikely to evolve incrementally on its own.

Though an important finding, it does not end the analysis. The question remains whether there is merit in trying purposively to create a field, of intervening to alter the likely default trajectory toward a Law of the Horse. It is well worth recalling that environmental law faced a similar crossroads in its early days. A Lawof-the-Horse approach was entirely possible, but it was rejected in favor of creating a new field that ultimately boasted its own statutes, agencies, and core principles such as internalizing externalities, risk management, and public involvement.

In retrospect, this was both outrageously ambitious and, by many measures, outrageously effective. Does it make sense to emulate this ambition and purposively intervene to create a distinct field for climate change adaptation? Motivated by that question, in Parts III and IV we explore what would justify and comprise a distinct law of climate change adaptation. The first step is to examine what a Lawof-the-Horse approach risks missing and what is really at stake in climate adaptation policy.

\section{A. Changing the Scale of Stationarity Assessment}

If, as we conclude, the Law of the Horse appears to be the natural path for law in response to climate change, what would justify an intervention to change that path? After all, we concluded in Part II that the vast majority of legal fields come through the Stationarity Assessment basically unscathed, and the few that will take some hits are likely to remain standing. Why is anything more needed? The answer lies in the scale at which the Stationarity Assessment is applied. 
Looking at climate change adaptation through the eyes of a single field of law allows careful analysis of the envelope of variability within which the field operates and on which its assumptions are based. Predicting the extent to which climate change will alter that envelope then allows one to consider how effectively the field's stationarity-based designs of the past will work in the climate change future. Focusing on one field of law thus identifies how assumptions of stationarity may break down for that field and allows for comparisons between fields to assess which are likely to undergo greater pressure to adapt or, at the extreme, to snap.

The disadvantage of the field-specific approach, however, is its failure to capture the cumulative effect of numerous intersecting fields undergoing stress on their respective stationarity-based foundations. It is one thing to observe that a field of law has managed change in the past and that climate change merely provides for similar evolution, albeit possibly at more frequent intervals or intense magnitudes. From this perspective, climate change adaptation may only require the field to work harder, with tinkering here and there.

In settings relevant to climate change adaptation, such as agriculture or coastal land use, the field-specific approach may suggest that each field comes through the Stationarity Assessment reasonably intact. But there is a further level of analysis needed. The aggregate effect of each field feeling moderate stress from climate change could lead to undetected cracks in the stationarity-based foundation of the system of fields working together. The most challenging climate adaptation questions are likely to be derived from complex environmental, social, and economic conditions that intersect across numerous fields. Viewed this way, climate change adaptation may demand more crosscutting responses from law than the field-specific focus led us to conclude.

It may not be, in other words, that climate adaptation law develops to replace any particular field but, rather, emerges to manage how those fields interact at scales relevant to climate adaptation decisionmaking. Decisions in these contexts will demand difficult policy tradeoffs and trigger different sets of questions depending on which way policy moves.

Consider, for example, the problem of domestic migration as people facing water scarcity, intense storms, and heat waves search for more hospitable environs. Widely regarded as a "complex challenge" of the climate change future, such migration waves will implicate "eight basic risks: loss of land, employment, shelter, and 
access to common resources; economic marginalization; increased morbidity and mortality; food insecurity; and negative cultural and psychological impacts."118 On a more local scale, consider this description of the hard choices that San Francisco, much like our case study's hypothetical coastal city, will confront as it begins to plan for sea-level rise:

[How to adapt to sea-level rise] presents enormously complex policy and economic issues both for existing communities and new development. There are several strategies for responding [to] sea level rise, ranging from protection (raising or building levees), to building "resilient" structures, to precluding new development in flood-prone areas, to abandoning existing built-up areas and retreating from the rising waters. The favored approach depends not only on the specific circumstances, but also on one's point of view regarding which values to protect. ${ }^{119}$

The choices among these options will have profound implications for and will lean heavily on land use controls, housing policy, publicand private-insurance providers, public-health services, coastalecosystem protection, emergency response, and public-infrastructure design and finance. Although it may be comforting to think that each of these legal fields can handle its piece of the policy dynamic, is there cause for concern that not all of the policy questions have been adequately addressed? We believe there is.

Of course, many coastal cities have had to deal on a regular basis with the realities of the coastal environment, including whether to promote or restrict coastal barriers and how much to regulate coastal development. But few cities have had to wrestle with whether they should finance and construct an enormous seawall system the length of the city's coastline, or retrofit all buildings and infrastructure to have greater resilience to floods, or just pack it up and move the entire city inland. Some of the legal fields working on the problem, for example, may experience much stronger interactions, such as the potential for land use decisions (moving inland) to put constraints on water-management decisions (how to get the water supply inland) and public-safety and health-services policy (how to serve the population that does not move inland). There may also be gaps in the

118. A. de Sherbinin et al., Preparing for Resettlement Associated with Climate Change, 334 SCIENCE 456, 457 (2011).

119. Zane Gresham \& Miles Imwalle, Sea Level Rise: Regulatory Responses in San Francisco Bay and Across the Globe, TRENDS, Jan.-Feb. 2010, at 10,10. 
law that are exposed by new policy questions, such as what to do if large numbers of people from other regions move into the area. Which field handles mass domestic migration? Certainly not immigration law.

Professors Verchick and Hall, in their work on flood- and stormadaptation policy, have explained how this problem already is clogging up development of adaptation policy at the federal level:

The cross-sector nature of adaptation makes things even worse. With so many government sectors having some relationship to climate resilience, it is unlikely that any single sector-based agency will "own" the issue. And that is why only a few sector-based agencies . . . think very much about adaptation at all: it's someone else's problem. Thus few agencies have developed specialized regulations or guidelines to promote climate resilience. Nor has Congress broadly directed agencies to focus on adaptation or created specific authorities for them to do so. ${ }^{120}$

Hence, although it may appear that most fields of law look to be in good shape when subjected to the Stationarity Assessment test, relying exclusively on field-specific assessments may lead to unwarranted complacency. So what is to be done?

\section{B. Adaptation as Process, Not Substance}

Consider the two basic approaches one could take to designing a field of climate change adaptation, one substantive and one procedural. Environmental law can provide a useful example of the formation of a substantive field. As described above, environmental law largely supplanted nuisance law as the primary regime for pollution problems when it became clear that the latter had simply been outstripped by changes in the nature of pollution. ${ }^{121}$ Nuisance law just was not up to the task. In its place, media-specific laws were adopted with national, uniform standards that would be implemented and enforced by a new environmental agency. ${ }^{122}$ Why not follow the same approach with climate change adaptation?

Developing a substantive body of law and policy for climate change adaptation may seem to be an attractive strategy at first glance. It certainly is easy to imagine climate change mitigation,

120. Verchick \& Hall, supra note 92, at 2223 (citation omitted).

121. See supra Part I.B.3.

122. See supra Part I.B.3. 
which is guided by simple objectives for pollution control (reducing greenhouse-gas emissions) and land use (preventing deforestation and increasing vegetative capacity to sequester carbon). But it is far less obvious how climate change adaptation translates into a substantive field of prescriptions and standards. Climate change adaptation is too crosscutting. Climate change will affect everywhere one way or another, but it will affect different areas in vastly different ways. What constitutes successful climate change adaptation will necessarily be different across the landscape ${ }^{123}$ Some areas will be fighting increased flooding while others fight increased drought. Moreover, adaptation measures will frequently have vertical and horizontal transboundary effects. One state adapting to longer growing seasons with increased irrigation could divert water supplies from another state facing reduced precipitation, and national waterinfrastructure policy could conflict with either or both states' adaptation goals. ${ }^{124}$ It is hard to imagine what a substantive climate adaptation law would even look like.

Consider also the institutional structure of emerging substantive fields of law. There is little doubt that the birth of the EPA helped to legitimize the environmental movement as a recognized field of law. A climate adaptation agency would face similar challenges implementing substantive laws. Given the vast breadth of sectors and activities implicated by climate change adaptation in so many different ways, it is hard to know what a regulatory body could meaningfully accomplish. In brief, attempting to construct a substantive law that could effectively and meaningfully address the myriad aspects of climate change adaptation seems a fool's errand.

By contrast, however, for the very reasons a substantive field would be too unwieldy to manage, a procedural strategy for climate change adaptation is far easier to envision. Once one considers systemic decisions that San Francisco and other regions will facewhether to construct a system of seawalls, to supply or not supply water to parched areas, or how to move a city inland-the shape of adaptation law and policy becomes much clearer. At those decision scales, climate change adaptation is a process. As a process, moreover, climate change adaptation intersects across many

123. See McDonald, supra note 18, at 288 ("[T] he highly localized nature of climate impacts also means that adaptation responses must also be tailored to local conditions ....").

124. John H. Davidson, Adapting to Climate Change: Transbasin Water Diversions and an Example from the Missouri River Valley, 11 Vt. J. Envtl. L. 757 (2010). 
substantive fields. Each discrete substantive issue-how high to build a seawall or how much water to divert to parched farms-is likely to match up well with some existing field of law. But none of the existing fields of law alone or in any combination are well equipped to manage the emergent process dimensions of climate change adaptation.

To make this clearer, consider the example of environmental justice. The need for a field of environmental justice arose precisely because substantive environmental law was operating as expected. The problem was that implementation of individual laws, when taken together, created an unintended problem. There was a systematic bias at work, as environmental harms and inadequate implementation routinely fell on poor communities of color. ${ }^{125}$ This was an emergent property that would not have been readily apparent in examining substantive air, water, or hazardous waste laws. It was only in assessing the process of their combined application that this problem and its scope became evident. Environmental justice thus focused in large part on identifying and correcting these systemic harms. ${ }^{126}$

In the same way, it may very well be that no existing field of law is rendered obsolete by climate change, but that more than a Law of the Horse is needed - that is, a distinct field of climate adaptation theory and practice is nonetheless necessary and appropriate to manage policy goals that no individual field can address. This need arises because the emergent harms from adapting to climate change are more likely to result from intersecting decisionmaking processes than from substantive legal doctrines. In simple terms, the difficult challenges will primarily be at the system level and will invoke the need for a new procedural field far more than a new substantive field.

\section{Designing A Field of Climate Change AdaPtation}

If climate adaptation policy is about process, it follows that climate adaptation law should be about process. In this Part we outline the policy goals and implementation mechanisms for a process-oriented field of climate change adaptation. Although perhaps not a field of law in the traditional sense of a substantive body of doctrine, like environmental justice, the new regime we propose is a procedural overlay—spanning multiple substantive fields

125. See supra Part I.B.2.

126. See supra Part I.B.2. 
to enforce overarching policy goals unlikely to be satisfied sufficiently were each substantive field left to enforce them independently. In this Part we outline the goals and mechanisms of such a procedural overlay for climate adaptation law.

\section{A. Policy Goals}

A procedural approach seems to make sense for climate change adaptation, but with what policy goals in mind? We argue that climate adaptation law is well suited for implementing three overarching normative goals lying at the heart of the emerging adaptation policy dialogue. The first two are reducing vulnerability and increasing resilience to climate change. ${ }^{127}$ These are related. ${ }^{128}$

Reducing vulnerability seeks to prevent climate change harms. This can be achieved by improving the reliability of infrastructure and other mechanisms designed to shield human communities and ecosystems from the harmful effects of climate change, such as by constructing sea walls to protect coastal areas or by limiting new development permits on coasts that are likely to experience sea-level rise. ${ }^{129}$ If the risks associated with vulnerability can be reduced

127. Vulnerability refers to "[t]he degree to which a system is susceptible to, or unable to cope with, adverse effects of climate change, including climate variability and extremes," and resilience refers to "[a] capability to anticipate, prepare for, respond to, and recover from significant multihazard threats with minimum damage to social well-being, the economy, and the environment." INTERAGENCY CLIMATE CHANGE ADAPTATION TASK FORCE, FEDERAL ACTIONS FOR A CLIMATE RESILIENT NATION 2 (2011), available at http://www.whitehouse.gov/ sites/default/files/microsites/ceq/2011_adaptation_progress_report.pdf.

128. See Intergovernmental Panel on Climate Change, Climate Change 2007: IMPACTS, ADAPTATION AND VULNERABILITY 720 (2007), available at http://www.ipcc.ch/ publications_and_data/publications_ipcc_fourth_assessment_report_wg2_report_impacts_adapt ation_and_vulnerability.htm ("Adaptation to climate change takes place through adjustments to reduce vulnerability or enhance resilience in response to observed or expected changes in climate and associated extreme weather events."); John Handmer \& Stephen Dovers, $A$ Typology of Resilience: Rethinking Institutions for Sustainable Development, in THE EARTHSCAN READER ON ADAPTATION TO ClimATE CHANGE, supra note 9, at 187, 196 (describing resilience and resistance as the opposite extremes of a continuum of possible responses to climate change); Nathan Hultman, Worth More Than Good Advice: Lessons of Hurricane Katrina for Development in a Changing Climate, 11 GEO. PUB. POL'Y REV. 47, 49-50 (2006) ("The first steps [in building resilience to natural disasters] involve executing the wellworn mantras of the disaster-relief community: build better protective infrastructure, initiate and enforce building codes, reduce environmental degradation, set policy to discourage settlement in vulnerable areas, and coordinate the disaster response to get immediate aid to those most in need.").

129. See Jonathan ENSOR \& RACHEL BERger, UNDERSTANDING Climate Change ADAPTATION: LESSONS FROM COMMUNITY-BASED APPROACHES 13-16 (2009) (delineating three different types of vulnerability to climate change and suggesting adaptations appropriate 
through such methods, less harm will be sustained and less capital will need to be deployed to recover from the effects of climate change.

But not all the risks of climate change can be mitigated by reducing vulnerability because costs, technological constraints, lack of knowledge, and mistaken assumptions will limit vulnerabilityreducing capacity. Increasing resilience thus focuses on recovering from harm caused by climate change impacts that could not be avoided, such as through improved emergency-response techniques and habitat-restoration methods. ${ }^{130}$

Many human communities and ecological landscapes will require a mix of these strategies to make effective use of available technological, financial, human, and social capital. ${ }^{131}$ But what is the right mix? Where do we deploy these strategies, for whom, and how? Questions such as these hold the potential to inform climate change adaptation at the ground level where policy decisions are put into practice.

The third goal, adaptation equity, is designed to ensure that the benefits of promoting resilience and reducing vulnerability are distributed fairly. ${ }^{132}$ Whose vulnerability is reduced and whose is worsened? The same for resilience. Climate mitigation policy has triggered rousing debates over the equitable allocation of costs

to each); P. Mick Kelly \& W. Neil Adger, Theory and Practice in Assessing Vulnerability to Climate Change and Facilitating Adaptation, in THE EARTHSCAN READER ON ADAPTATION TO ClimATE CHANGE, supra note 9, at 161, 162-74 (exploring the definition of vulnerability and how to operationalize a response to climate change).

130. See ENSOR \& BERGER, supra note 129, at 17-25 (setting out a list of elements included in adaptive capacity); Handmer \& Dovers, supra note 128, at 190-204 (proposing a typology of resilience based on the type of change, ecology concerns, and risk-management concerns).

131. Blending the two strategies together is often described under the label of "adaptive capacity." See, e.g., INTERgovernmental PANEL ON ClimATE CHANGE, supra note 128, at 56 (describing how some indigenous communities are adapting in multiple ways but also noting that the multiple stressors "will challenge [their] adaptive capacity"); Brian H. Hurd, Challenges of Adapting to a Changing Climate, 26 UCLA J. ENVTL. L. \& POL'Y 77, 81 (2008) ("[A] community's adjustment opportunities and adaptive capacity are founded on its capability to protect and secure vital physical and social infrastructure, to access financial resources, to harness information and 'know how' (human capital), and to deploy appropriate technology in the face of or anticipation of adverse events or changes.").

132. See, e.g., McDonald, supra note 18, at 287-88 (noting the disparate impacts of climate change on disadvantaged groups as the reason why "domestically, adaptation policies will need to address the social justice implications of climate change and the laws that implement adaptation policies must themselves minimize potential discrimination or social injustices"). For a thorough review of climate adaptation equity, see generally Alice Kaswan, Domestic Climate Change Adaptation and Equity, 42 ENVTL. L. REP. 11,125 (2012). 
between nations and within nations. ${ }^{133}$ More recently, climate change adaptation has moved to center stage in the international arena, as poor coastal and small-island nations most in harm's way argue that the developed world should finance their adaptive measures. ${ }^{134}$ Little attention, however, has been paid to how to equitably allocate adaptation benefits within the United States, but this is sure to become a highly charged issue..$^{135}$

As an example, consider again our coastal region described in Part II. ${ }^{136}$ Vulnerability focuses on protecting inhabitants from more frequent and intense storm surges and heat waves. Resilience focuses on recovering from the damage caused by flood and heat-wave events when they happen. And adaptation equity seeks to ensure that measures reducing vulnerability and increasing resilience do not disadvantage specific groups. Much as environmental justice has sought to enforce equity norms in the implementation of environmental law and policy, this new field would use the metrics of vulnerability, resilience, and equity to evaluate decisions about

133. See generally, e.g., Simon Caney, Cosmopolitan Justice, Rights and Global Climate Change, 19 CAN. J.L. \& JURISPRUDENCE 255 (2006); John H. Knox, Climate Change and Human Rights Law, 50 VA. J. INT'L L. 163, 165 (2009); John H. Knox, Linking Human Rights and Climate Change at the United Nations, 33 HARv. ENVTL. L. REV. 477 (2009); Siobhán McInerney-Lankford, Climate Change and Human Rights: An Introduction to Legal Issues, 33 HaRV. ENVTL. L. REV. 431 (2009); Stephen Tully, The Contribution of Human Rights as an Additional Perspective on Climate Change Impacts Within the Pacific, 5 N.Z. J. PUB. \& INT'L L. 169 (2007).

134. See, e.g., William C. Burns, Global Warming-The United Nations Framework Convention on Climate Change and the Future of Small Island States, 6 DICK. J. ENVTL. L. \& POL'Y 147, 175 (1997); John Crump, Snow, Sand, Ice, and Sun: Climate Change and Equity in the Arctic and Small Island Developing States, SuSTAINABLE DEV. L. \& POL'Y, Spring 2008, at 8, 8-10; Alexander Gillespie, Small Island States in the Face of Climatic Change: The End of the Line in International Environmental Responsibility, 22 UCLA J. ENVTL. L. \& POL'Y 107, 121-22 (2004); Susan Glazebrook, Human Rights and the Environment, 40 VICTORIA U. WELLINGTON L. REV. 293, 342 (2009).

135. See generally, e.g., Maxine Burkett, Just Solutions to Climate Change: A Climate Justice Proposal for a Domestic Clean Development Mechanism, 56 BUFF. L. REV. 169 (2008); Jacqueline P. Hand, Global Climate Change: $A$ Serious Threat to Native American Lands and Culture, 38 ENVTL. L. REP. 10,329 (2008); Alice Kaswan, Environmental Justice and Domestic Climate Change Policy, 38 EnvtL. L. REP. 10,287 (2008); Robert R.M. Verchick, Adaptive Justice, in Climate Change: A ReAder 881 (William H. Rodgers, Jr., Michael RobinsonDorn, Jennifer K. Barcelos \& Anna T. Moritz eds., 2010). For a discussion of how some prominent figures in the religious evangelical community have begun to portray climate change as a human rights issue, see John Copeland Nagle, The Evangelical Debate over Climate Change, 5 U.ST. THOMAS L.J. 53 (2008).

136. See supra Part II.A. 
building construction, agricultural incentives, transportation networks, threat disclosures, and other adaptive activities.

\section{B. Procedural Overlay Implementation Mechanisms}

The central point made in Part III is that the decisionmaking challenges of climate change adaptation span across many fields of law and will frequently address questions that no existing field of law is capable of managing. It follows, therefore, that the procedural approach used for climate adaptation law must operate at the same level at which the emergent policy questions of vulnerability, resilience, and equity operate. In terms of implementation, there is any number of specific approaches that a field of climate change adaptation could take to drape this procedural overlay on top of the substantive fields of law tarred by climate change's brush. We set out a range of options below.

One could follow the strategy of the National Environmental Policy Act (NEPA), ${ }^{137}$ which requires federal agencies to consider the impacts of major federal actions that significantly affect the environment. Similar to NEPA's requirement of drafting an environmental impact statement to inform the decisionmaking process, agencies and decisionmakers would assess the cumulative impacts of their adaptation actions and the implications for vulnerability, resilience, and distributional equity. ${ }^{138}$ Unlike NEPA, however, this process would go well beyond environmental impacts to include significant social and economic aspects of adaptation decisions. Operating at the state or federal level, the review requirement could be triggered by a specific spending level for projects or the significance of likely impacts. The agencies involved would create a joint review with public notice and comment, ensuring through that exercise alone that communication would occur among the key parties operating in different substantive fields.

137. National Environmental Policy Act of 1969, 42 U.S.C. $\$ \S 4321-4347$ (2006 \& Supp. IV 2011).

138. For critiques of NEPA in the climate adaptation context, see, for example, Caleb W. Christopher, Success by a Thousand Cuts: The Use of Environmental Impact Assessment in Addressing Climate Change, 9 VT. J. ENVTL. L. 549, 564 (2008) (proposing adaptive approaches for NEPA in the climate change context); Daniel A. Farber, Adaptation Planning and Climate Impact Assessments: Learning from NEPA's Flaws, 39 ENVTL. L. REP. 10,605, 10,607-13 (2009); Daniel A. Farber, Modeling Climate Change and Its Impacts: Law, Policy, and Science, 86 TEX. L. REV. 1655, 1690 (2008); and Katherine M. Baldwin, Note, NEPA and CEQA: Effective Legal Frameworks for Compelling Consideration of Adaptation to Climate Change, 82 S. CAL. L. REV. 769,789 (2009). 
NEPA is a reflexive statute, relying on information compiled at the time of decisionmaking to improve decision outcomes. ${ }^{139}$ Agencies complying with NEPA must consider the environmental impacts of a range of alternatives. ${ }^{140}$ There is no requirement, however, to choose the environmentally preferable option.

For an approach with teeth, one could borrow from the comprehensive planning tradition of land use law ${ }^{141}$ to envision a state law requiring cities to develop climate adaptation master plans covering the breadth of adaptation policy. These plans would serve as the reference point for requiring consistency with the plan's goals and details in decisions regarding land use, water management, environmental protection, public health, and other policy agendas directly connected to and affected by adaptation decisions. Similarly, an independent state agency could oversee implementation of this statute and provide both expertise and guidance to local decisionmakers seeking to address the impacts of climate change.

Building on the plan-consistency model, federalism concerns could be addressed by adding a layer of plan consistency above the state-local level in the same manner as the Coastal Zone Management Act (CZMA) ${ }^{142}$ currently does for coastal-land management. ${ }^{143}$ Under the CZMA, the federal government entices the states to develop and enforce coastal-zone land use management plans that meet federally defined goals not only with federal funding support, ${ }^{144}$ but also with the agreement not to carry out, fund, or finance federal actions that would conflict with the state plan. ${ }^{145}$ Similarly, the federal government could both support state development of adaptation plans according to federally defined adaptation goals and agree to conform federal decisionmaking to those state plans. This allows uniform overarching federal policy goals to guide state planning, but at the same time responds to the need to

139. 42 U.S.C. $\$ 4332$.

140. Agency Decisionmaking Procedures, 40 C.F.R. $\S 1505.1$ (2012).

141. See generally CALLIES ET AL., supra note 115, at 458-71 (providing several examples of local enforcement of land use law).

142. Coastal Zone Management Act, 16 U.S.C. \$\& 1451-1464 (2006 \& Supp. V 2012).

143. See JOHN COPELAND NAGLE \& J.B. RUHL, THE LAW OF BIODIVERSITY AND ECOSYSTEM MANAGEMENT 761-80 (2d ed. 2006) (describing the laws that impact beaches and coastal lands).

144. 16 U.S.C. \& $1456(a)$.

145. Id. § $1456(\mathrm{c})$. 
accommodate different conditions across states, which are likely to vary widely under climate change. ${ }^{146}$

Borrowing from the citizen-suit tradition of environmental law, ${ }^{147}$ one could take a more decentralized approach. A statute could define the three normative goals of adaptation policy and require agencies engaging in adaptation investments to ensure that they plan for adherence to those goals, with a private cause of action available to the public as a mode of enforcement. Citizen-suit litigation is, for example, the engine of enforcement for the Endangered Species Act's requirement that federal agencies assess the impacts of their actions on protected species.

To be sure, there are obvious disadvantages to each of these approaches. Environmental justice has been criticized as window dressing, a politically correct gloss for environmental law and policy decisions that pay little attention to distributional equity. ${ }^{148}$ NEPA has been dismissed as a resource-intensive post hoc rationalization of decisions that have already been made. ${ }^{149}$ And, equally, there are rebuttals to these critiques. ${ }^{150}$ Our goal here is not to advocate for any particular implementation model, but to show that there are numerous implementation mechanisms tried and tested in analogous

146. See Robert L. Glicksman, Climate Change Adaptation: A Collective Action Perspective on Federalism Considerations, 40 ENVTL. L. 1159, 1176-91 (2010) (exploring federalism issues in the context of climate adaptation).

147. See generally James R. May, Now More Than Ever: Trends in Environmental Citizen Suits at 30, 10 WIDENER L. REV. 1 (2003).

148. See, e.g., U.S. Gov'T ACCOUNTABILTY OfFICE, GAO-12-77, ENVIRONMENTAL Justice: EPA NeEdS To TAKE AdDitional ACTIONS To HelP ENSURE EFFECTIVE IMPLEMENTATION 22 (2011), available at http://www.gao.gov/assets/590/585654.pdf (arguing that, despite years of efforts to implement an environmental justice plan within the agency, the "EPA cannot assure itself, its stakeholders, and the public that it has established a framework to effectively guide and assess its efforts to integrate environmental justice into the fabric of the agency").

149. The Council on Environmental Quality, for example, convened a NEPA Task Force to hold hearings and review the statute's operation. It reported that "[m]any respondents believe that the general requirement to provide adequate analysis has been taken to an extreme, that documents have become unconscionably time-consuming and costly to produce, and that the resultant 'analysis paralysis' forestalls appropriate management of public lands and ultimately leaves the public distrustful and disengaged." CEQ TASK FORCE, REVIEW OF THE NEPA PROCESS, at v (2002), available at http:/ceq.hss.doe.gov/ntf/catreport.

150. See, e.g., Press Release, Natural Res. Def. Council, Defending NEPA from Assault (May 24, 2005), available at http://www.nrdc.org/media/pressreleases/021003.asp ("For over 30 years, NEPA has provided an essential tool in helping federal managers do their jobs. When done right, it promotes sound and accepted decisions."). 
contexts that could provide frameworks for constructing a new field of climate adaptation law and policy.

\section{CONCLUSION}

Most of the attention that legal scholars have given to climate change adaptation has focused on how it will affect substantive fields of law. There is an almost intuitive sense that because climate change will wreak havoc, law and policy will necessarily transform across numerous fields as well, even to the point of demanding an altogether new field of law devoted directly to managing climate change adaptation.

As we have shown through the Stationarity Assessment model, however, the climate change-equals-legal-change premise is leading down the wrong path. The intuition is on point-climate change adaptation demands special attention in law and policy-but the focus on substantive doctrine is off track. In short, it is not a new field of substantive law that is needed-the Law of the Horse will work fine at that level-but rather a new field of procedural law. And the experience of environmental justice is particularly relevant here. Just as environmental justice provides a distributional-equity prism to assess the impacts of environmental law so, too, could a field of climate change adaptation provide a powerful procedural framework for assessing the legal and policy responses to climate change impacts. Recall that environmental law largely supplanted nuisance law primarily because nuisance doctrine was substantively inadequate to manage modern pollution problems. By contrast, environmental justice did not replace anything and is not a substantive body of law. It emerged initially to fill a procedural gap in environmental law decisionmaking - the need to ensure just distributional effects-and later broadened its theory and practice as an overlay across many fields.

Climate change adaptation may become yet another Law of the Horse, and that might be appropriate. But this is not preordained. Other fields of law will eventually have to adapt to climate change, that much is clear. Whether the net result of independent evolution sufficiently reduces vulnerability, increases resilience, and ensures distributional equity, however, is far less clear.

The lawyers who gathered to justify and design environmental law and environmental justice were not satisfied with how the Law of the Horse looked to them. Could lawyers and policymakers similarly 
gather around a table tomorrow and ask, "What are we trying to do with climate adaptation law and policy in the big picture? What should the cumulative role of law and policy be in this emerging area? How can we ensure law evolves in that direction?" Rather than waiting to see how the Law of the Horse works out for climate change adaptation, we argue that this is a discussion that can and should take place now. 
*** 